\title{
33. CHARACTERIZATION OF SORBED VOLATILE HYDROCARBONS FROM THE PERU MARGIN, LEG 112, SITES 679, 680/681, 682, 684, AND 686/6871
}

\author{
Michael J. Whiticar ${ }^{2}$ and Erwin Suess ${ }^{3,4}$
}

\begin{abstract}
Bacterial and thermogenic hydrocarbons are present in the sorbed-gas fraction of Peru margin sediments. At Ocean Drilling Program (ODP) Sites 681, 682, 684, and 686, bacterial gases are restricted to the early diagenetic zones, where dissolved sulfate has been exhausted and methanogenesis occurs. Methane migrating into the sulfate zone at Sites $681,684,686$, and possibly 682 , has been consumed anaerobically by methanotrophs, maintaining the low concentrations and causing an isotope shift in $\delta^{13} \mathrm{C}_{\mathrm{CH}_{4}}$ to more positive values. Significant amounts of $\mathrm{C}_{2+}$ hydrocarbons occur at the shelf Sites $680 / 681,684$, and $686 / 687$, where these hydrocarbons may be associated with hypersaline fluids. There is evidence at Site 679 that sorbed $C_{2+}$ hydrocarbons may also have been transported by hypersaline fluids. This characteristic $\mathrm{C}_{2+}$ hydrocarbon signature in the sorbed-gas fractions of sediments at Site 679 is not reflected in data obtained using the conventional "free-," "canned-," or "headspace-gas" procedures. The molecular and isotope compositions of the sorbed-gas fraction indicate that this gas may have a thermogenic source and may have spilled over with the hypersaline fluids from the Salaverry Basin into the Lima Basin. These traces of thermogenic hydrocarbon gases are over-mature (about $1.5 \% \mathrm{Ro}$ ) and are discordant with the less-mature sediments in which they are found.

This observation supports the migration of these hydrocarbons, possibly from continental sources. Sorbed-gas analyses may provide important geochemical information, in addition to that of the free-gases. Sorbed-gases are less sensitive to activities in the interstitial fluids, such as methanogenesis and methanotrophy, and may faithfully record the migration of hydrocarbons associated with hypersaline fluids.
\end{abstract}

\section{INTRODUCTION}

Continental margin sediments off central Peru contain an enormous amount and variety of organic matter derived from coastal upwelling productivity (Farrimond et al., Suess et al., Whelan et al., this volume). The use of biological markers, an approach that links complex organic compounds to specific biological sources, yields important environmental information from this sizable carbon reservoir (Farrimond et al., Kvenvolden et al., Repeta, ten Haven, et al., this volume). The high organic matter content also fuels vigorous syndepositional and post-depositional alteration, which is dominated initially by microbial sulfate reduction (sulfate-reducing bacteria $=\mathrm{SRB}$ ), followed by methanogenesis through carbonate reduction (Thornburg and Suess, this volume). These processes contribute to a variety of organic compounds. Bacterial methane, in particular, reaches considerable concentrations, even sufficient to form gas hydrates (Kvenvolden and Kastner, this volume). Sorbed organic matter is a small pool of the total organic carbon reservoir in these sediments and is somehow associated with and stabilized by the mineral content (Suess and Müller, 1980).

Sorbed hydrocarbons in the volatile range $\left(\mathrm{C}_{1}\right.$ through $\left.\mathrm{C}_{5}\right)$ usually occur in low concentrations; their exact source, transport mobility, and stabilization against microbial and thermal alteration is poorly understood. Sediments of the Peru margin drilled during Leg 112 offer scientists the opportunity to examine the range of sorbed volatile hydrocarbons associated

\footnotetext{
${ }^{1}$ Suess, E., von Huene, R., et al., 1990. Proc. ODP, Sci. Results, 112: College Station, TX (Ocean Drilling Program).

2 Bundesanstalt für Geowissenschaften und Rohstofte, Stilleweg 2, 3000 Hannover 51, Federal Republic of Germany.

${ }^{3}$ College of Oceanography, Oregon State University, Corvallis, OR 97331.

${ }^{4}$ Now at GEOMAR, Research Center for Marine Geosciences, Wischhofstrasse 1-3, $2300 \mathrm{Kiel} 14$, Federal Republic of Germany.
}

with the mineral matrix and to determine the role of the geochemical environment on their distribution, specifically, whether (1) sorbed volatile hydrocarbons exhibit an affinity in composition and stable isotope characteristics to the free hydrocarbon gases, (2) their distribution may be controlled by clay minerals or sediment provenance, and (3) their ultimate source and mobility can reasonably be inferred.

Here, we report the results of shore-based hydrocarbon gas analyses from seven drill sites occupied during ODP Leg 112. Sites $680 / 681,684$, and $686 / 687$ are located in the shelf basins of Salaverry, Trujillo, and West Pisco at water depths between 151 and $447 \mathrm{~m}$ (von Huene, Suess, et al., 1988). These sites receive direct influx from three coastal upwelling areas centered around $9^{\circ}, 11^{\circ}$, and $13^{\circ} \mathrm{S}$ latitude, respectively (Fig. 1). The three basins differ in their rate of sedimentation. The fastest deposition took place at Sites $686 / 687$, intermediate deposition occurred at Site 680 , and the slowest deposition was at Site 684. The two other sites, 679 and 682, lie along a westward extension of Site 680 , beyond the shelf edge on the upper slope (Site 679; water depth of $440 \mathrm{~m}$ ) and middle slope (Site 682; water depth of $3789 \mathrm{~m}$ ).

The subsurface of the shelf basins has been permeated by a strongly saline brine that apparently moves from the central shelf northward toward Site 684 and southward toward Sites 686/687 (Kastner et al., this volume; Suess, von Huene, et al., 1988). Site 679 is located at the westernmost extent of this subsurface brine. Here, the Quaternary/ Pliocene units are influenced by the brine, while the Miocene units are unaffected. Site 682 is located outside the range of the shelf brine and, unlike the shelf sites, receives sediments that are reworked by bottom currents. The mean rate of sedimentation is high for a deep-water site and, hence, comparable to most of the shelf sites. In all respects, Site 682 may serve as a remote reference environment with which the sorbed hydrocarbons from the shelf setting may be compared. 


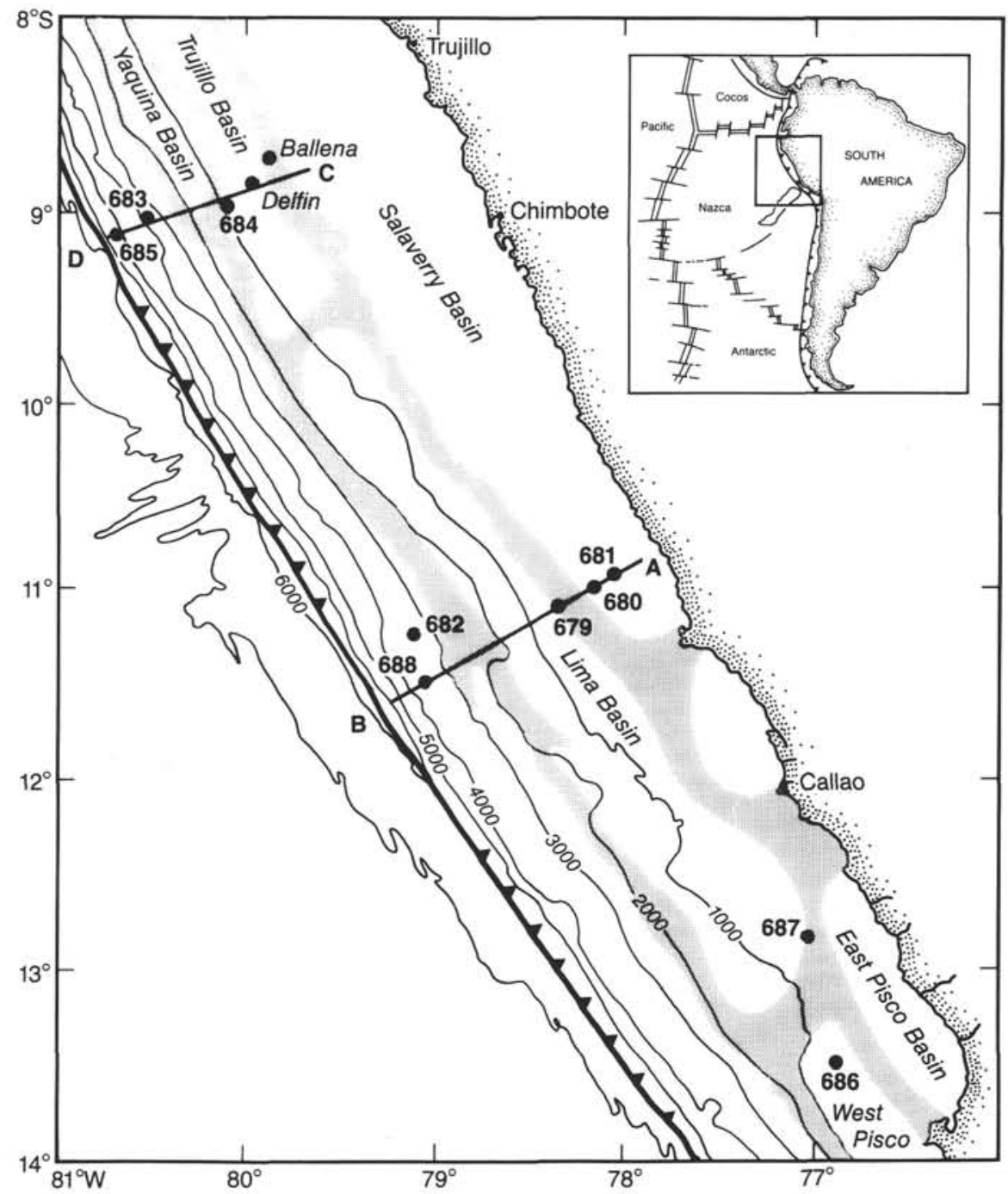

Figure 1. Location map of Leg 112 sites and basins with postulated subsurface brines.

\section{PROCEDURES}

Hydrocarbon gases are characterized by their molecular and stable isotope $\left({ }^{13} \mathrm{C} /{ }^{12} \mathrm{C}\right.$ and $\left.\mathrm{D} / \mathrm{H}\right)$ compositions, in conjunction with their environmental setting; i.e., primary upwelling facies, reworked facies with and without brine influence. The analytical procedure used here is that previously described for samples of Leg 104 (Whiticar and Faber, 1989). Briefly, two hydrocarbon gas fractions are distinguished according to their retention in the sediment: "free", and "sorbed" gases.

The free-gas fraction represents the unbound or only weakly bound gases situated primarily in the interstices of the sediment fabric. Generally, these gases are dissolved in the interstitial fluids, or sometimes occur as gas or hydrate phases. Analysis of this gas fraction is comparable to other shipboard procedures, commonly referred to as "cannedgas," "headspace," and "vacutainer" analyses (see Kvenvolden et al., this volume). Sediment samples for analysis of the sorbed-gas fraction are routinely pretreated by washing and sieving $(<63 \mu \mathrm{m})$ and by pumping off the free gas. The sorbed gases are those that are then released (desorbed) from the pretreated sediment through rigorous vacuum degassing with boiling phosphoric acid (Faber and Stahl, 1983).

The 54 samples reported here were stored frozen $\left(-12^{\circ} \mathrm{C}\right)$ immediately after extrusion from the core catcher on board the JOIDES Resolution. These samples were then analyzed for the sorbed-gas fraction using a modified version of this technique. Our analytical procedure deviated from the above in that the samples were not washed or sieved, but only the free gases were pumped away before acidification and desorption. This analytical arrangement was necessitated by the small amounts of sediment sample available (sample wet weight ranges from $35.9 \mathrm{~g}$ min. to $177.5 \mathrm{~g}$ max.). Despite this change in procedure, we are confident that, in general, this fraction is still representative of the "true sorbed" fraction. To evaluate this assumption, we separately analyzed five samples, from which adequate amounts of sediment were available, for their "free" and "true sorbed" (washed and pumped) gas fractions to demonstrate that "sorbed" fractions from the two techniques (washed and unwashed) are essentially identical. In addition, we also separated one sample (112-679D-5H, CC) into the size fractions, $>63 \mu \mathrm{m}$ and $<63$ 


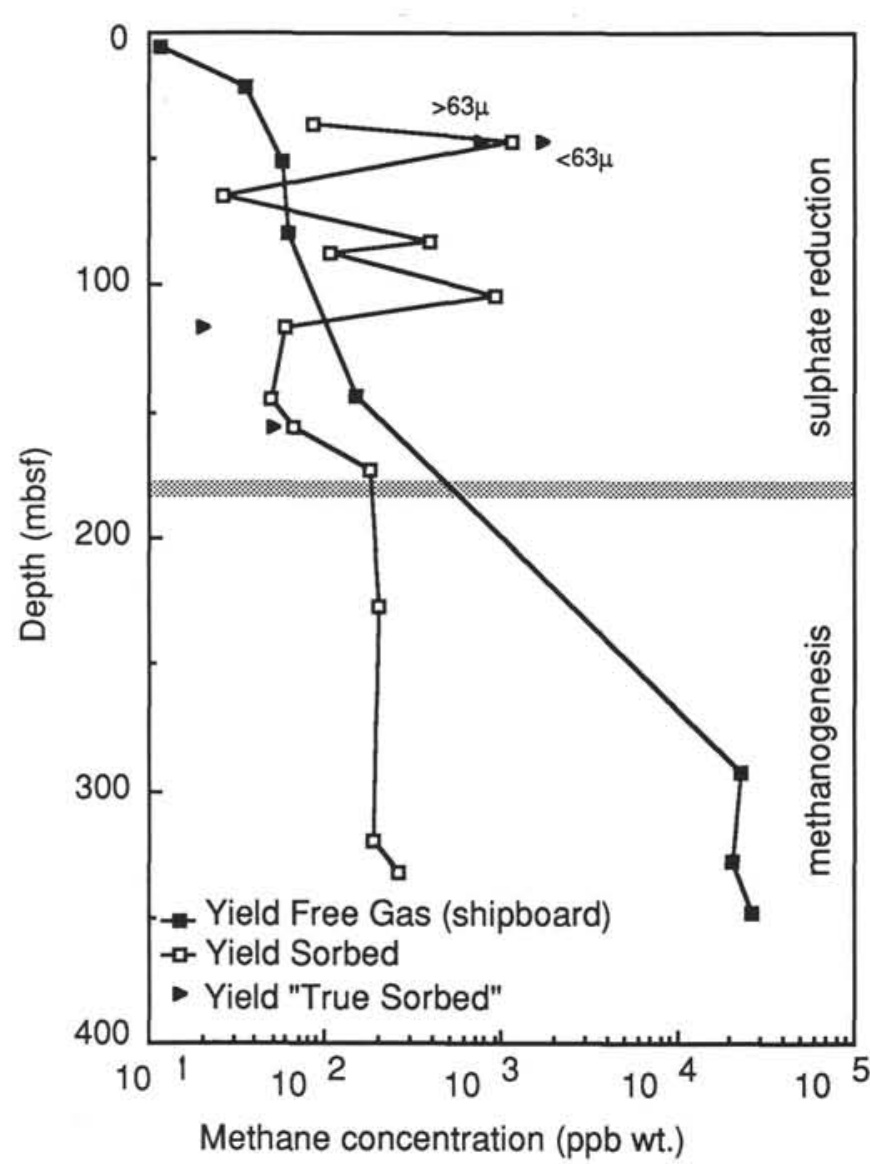

Figure 2. Comparison of methane yields from different shipboard and BGR analytical procedures on samples from Site 679.

$\mu \mathrm{m}$, by washing and sieving and then analyzed the sorbedgases separately.

Results of this comparison are illustrated in Figure 2, in which the downcore distributions of three methane fractions (sorbed, free, and "true sorbed") are shown for Site 679. For comparison, the "canned-gas" $\mathrm{CH}_{4}$, determined on board the ship (Shipboard Scientific Party, Site 679, 1988; Kvenvolden et al., this volume), is shown. Clearly, the $\mathrm{CH}_{4}$ concentration of the sorbed fraction is representative, in these cases, of the "true sorbed" $\mathrm{CH}_{4}$. Interestingly, the data in Figure 2 also confirm that the "canned-gas" procedure yields only "freegas" hydrocarbon component and is roughly comparable to the "headspace" analytical technique.

A wide range in concentration (more than three orders of magnitude) is exhibited by the free-gas, in response to bacterially mediated, diagenetic reactions. The "free" $\mathrm{CH}_{4}$ concentration is maintained at a low level in the sulfate zone by the methanotrophs. Below the zone of microbial sulfate reduction, where methanogenic carbonate reduction is pervasive, biogenic methane rises to high concentrations and dominates the total gas content of the sediment. As is discussed later in detail, the sorbed-gases generally have a much more restricted range in concentration.

The molecular compositions of the various gas fractions were quantified by conventional analytical gas chromatography. Their concentrations are reported on a dry weight basis in parts per billion (ppb), e.g., yield $C_{1}(\mathrm{ppb})=\mathrm{g} \mathrm{C}_{1} / 10^{9} \mathrm{~g}$ dry sediment. The total hydrocarbon yield (total hc yield) is the sum of the hydrocarbon yields of the individual alkanes, $C_{1}$, $\mathrm{C}_{2}, \mathrm{C}_{3}, i-\mathrm{C}_{4}$, and $n-\mathrm{C}_{4}$. Hydrocarbons with higher molecular weights $\left(\mathrm{C}_{5}, \mathrm{C}_{6}, \mathrm{C}_{7}\right)$ were also determined, but these are

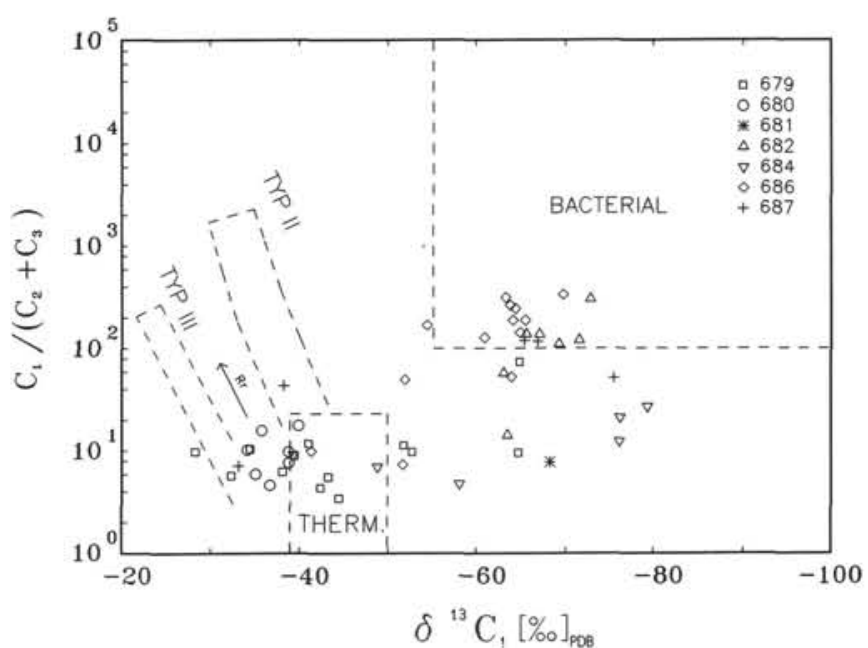

Figure 3. Interpretative plot of $\mathrm{C}_{1} /\left(\mathrm{C}_{2}+\mathrm{C}_{3}\right)$ vs. $\delta^{13} \mathrm{C}_{\mathrm{CH}_{4}}$, combining all Leg 112 sites and indicating thermogenic and bacterial gas sources (latter possibly from Type II/III kerogen).

reported only qualitatively because of possible condensation losses during gas transfers. The yield $\mathrm{C}_{2+}$ is the yield sum of $\mathrm{C}_{2}+\mathrm{C}_{3}+i-\mathrm{C}_{4}+n-\mathrm{C}_{4}$. The compositional ratio $\mathrm{C}_{1} / \mathrm{C}_{2+}=$ $\mathrm{C}_{1} /\left(\mathrm{C}_{2}+\mathrm{C}_{3}+i-\mathrm{C}_{4}+n-\mathrm{C}_{4}\right)$ is expressed on a volume-percent (vol\%) basis, as is the normalized hydrocarbon volumepercent $(\mathrm{hc} \%)$. The olefins, ethene and propene $\left(\mathrm{C}_{2:}\right.$ and $\mathrm{C}_{3:}$, respectively) were also determined and reported, but these are not discussed in detail.

Hydrocarbon gases were prepared for isotope measurement by gas chromatographic partitioning, followed by combustion over $\mathrm{CuO}$ at $880^{\circ} \mathrm{C}$, and collection of the resultant $\mathrm{CO}_{2}$ and $\mathrm{H}_{2} \mathrm{O}$. The ${ }^{13} \mathrm{C} /{ }^{12} \mathrm{C}$ ratios of methane, ethane, and propane were measured using an isotope ratio mass spectrometer at BGR, Hannover. Enough combustion water was available from several methane samples for $\mathrm{D} / \mathrm{H}$ ratio (i.e., ${ }^{2} \mathrm{H} /{ }^{1} \mathrm{H}$ ) measurements by reduction of $\mathrm{H}_{2} \mathrm{O}$ on zinc to molecular $\mathrm{H}_{2}$.

The stable isotope data are presented in the usual $\delta$ notation:

$$
\delta R_{\mathrm{A}}(\% o)=\left[\frac{R_{\mathrm{A}} / R_{\mathrm{B}} \text {-sample }}{R_{\mathrm{A}} / R_{\mathrm{B}}-\text { Standard }}-1\right] \times 10^{3},
$$

where $R_{A} / R_{B}$ is ${ }^{13} \mathrm{C} /{ }^{12} \mathrm{C}$ and $\mathrm{D} / \mathrm{H}$, relative to $\mathrm{PDB}$ and SMOW standards, respectively.

\section{RESULTS}

The diversity of geologic setting and geochemical environment of the samples is reflected in the molecular and isotope data of the sorbed volatile hydrocarbon gases. These data are presented in Tables 1 and 2 . Next, we discuss these data in conjunction with other geochemical parameters on a siteby-site basis and characterize the various gas types. Then, we interpret the gas types in terms of potential sources related to the regional framework and geochemical environment (Figs. 3 and 4).

\section{Site 679}

Site 679 shows the widest range in sorbed-gas content. Located on the eastern flank of the Lima Basin, oceanward of the outer shelf high, Site 679 terminates in middle Miocene sediments at 359.3 meters below seafloor (mbsf). Character of the hydrocarbon gases at Site 679 is very different in the lower 


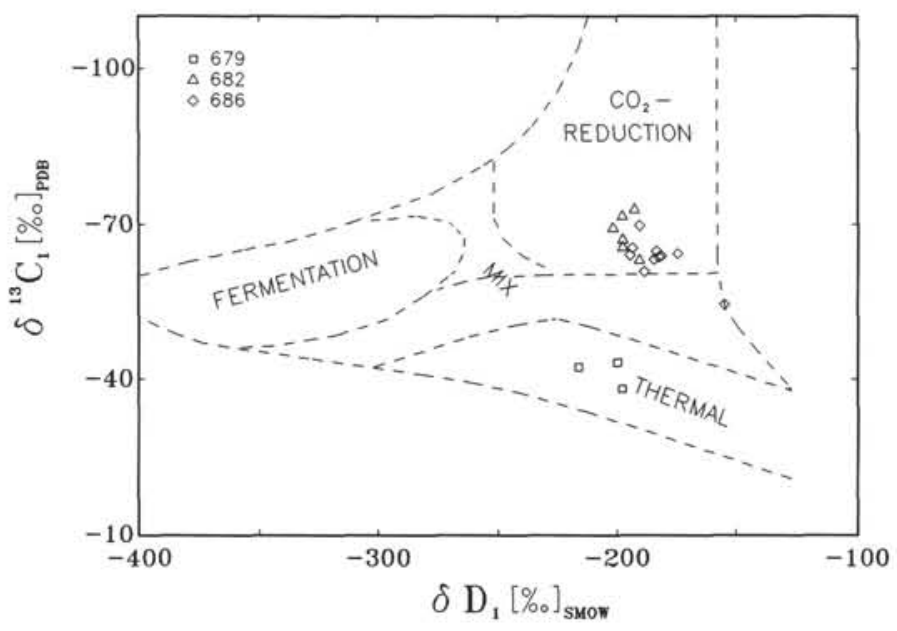

Figure 4. Interpretative plot of $\delta^{13} \mathrm{C}_{\mathrm{CH}_{4}}$ vs. $\delta \mathrm{D}_{\mathrm{CH}_{4}}$, showing the bacterial gas (through $\mathrm{CO}_{2}$-reduction pathway) and thermogenic gas types.

Quaternary and Pliocene sediments (lithologic Units I and II) than in the upper and middle Miocene sediments (Units III and IV). The change is sharp and occurs at the Miocene/ Pliocene boundary at $110 \mathrm{mbsf}$.

In the uppermost core section, between 36.1 and 104.3 mbsf, the total sorbed hydrocarbon yield $\left(\mathrm{C}_{1}+\mathrm{C}_{2}+\mathrm{C}_{3}+i\right.$, $n-\mathrm{C}_{4}$ ) varies between 53 and $1830 \mathrm{ppb}$ (Fig. 5). Methane is the primary light hydrocarbon gas present, making up 74 to 91 hc\%. In this core section, ethane and propane account for the majority of the $\mathrm{C}_{2+}$ hydrocarbons, with respective yields ranging from 10.3 to $262 \mathrm{ppb}(6.4$ to $15.6 \mathrm{hc} \%)$ and 4.2 to 120 ppb (2.0 to $6.1 \mathrm{hc} \%)$. These concentrations, especially the $\mathrm{C}_{2+}$ components, are higher than expected for the sediment types present and the geochemical environment of anoxic early diagenesis. Moreover, they are anomalously high in view of the hydrocarbon gas contents of the core sections deeper than $104 \mathrm{mbsf}$, where the total is quite low (yield about 59 to $262 \mathrm{ppb}$ ).

The highest gas contents were measured in diatomaceous Pliocene muds (Unit II). These sediments are generally high in organic carbon $\left(\mathrm{C}_{\text {org }}\right.$ is 3.9 to $10.4 \%$, mean $\left.6.7 \%\right)$ and significantly elevated over the deeper Miocene units $\left(C_{\text {org }} 0.23\right.$ to $2.2 \%$, mean $0.73 \%$ ), although the three samples having the highest sorbed-gas contents do not coincide with maximum organic carbon contents. Gas enrichment in this zone is also accompanied by traces of increased pore-fluid salinity (Shipboard Scientific Party, 1988a) and in the sediment fabric by extensional microfaults, fractures or tension gashes, by dewatering veins, and other pore-fluid escape structures.

The chloride concentration of the middle Miocene sediments below 275 mbsf indicate that pore fluids are influenced by freshwater. Dissolved sulfate of these deeper sediments decreases below $1 \mathrm{mM}(\mathrm{mmol} / \mathrm{L})$ at $292.7 \mathrm{mbsf}$, in contrast to the Pliocene sediments where sulfate concentrations are $17 \mathrm{mM}$ or greater. This decrease is partly due to the deeper freshwater intrusion, but also due to uptake of sulfate by the SRB. The onset of methanogenesis corresponds to the exhaustion of sulfate in the deeper sections of the hole and, hence, to the production of enormous amounts of bacterial methane (Kvenvolden and Kastner, this volume).

In the upper section of Site 679 , the $\delta^{13} \mathrm{C}_{\mathrm{CH}_{4}}$ varies from -38.1 to $-44.4 \%$, with a mean of $-39 \%$ (Fig. 5). (Note: $\delta^{13} \mathrm{C}_{\mathrm{CH}_{4}}=-28.3 \%$ at $86.62 \mathrm{mbsf}$ is questionable because of low gas contents.) The combination of the methane carbon isotope ratios with the corresponding molecular $\mathrm{C}_{1} /\left(\mathrm{C}_{2}+\mathrm{C}_{3}\right)$ ratios of 3.4 to 9.8 , indicates a thermogenic source for these gases (Fig. 3). The three $\delta \mathrm{D}_{\mathrm{CH}_{4}}$ values of -198 to $-216 \%$, shown in Figure 4, further support this interpretation. Below 150 mbsf, the shift in $\delta^{13} \mathrm{C}_{\mathrm{CH}_{4}}$ to $-64.9 \%$ signals the onset of bacterial methanogenesis, as seen in the free-gas distribution. However, the influence of thermogenic gas appears to persist with depth with respect to the carbon isotope signature, particularly at 319.5 mbsf; however, the signature is partly masked by the admixture of bacterial gas, which creates a wider range in isotope values.

\section{Sites $680 / 681$}

The sorbed hydrocarbon content of the sediments at Site 680 in the Salaverry Basin is low (total yield $=32$ to $84 \mathrm{ppb}$ ), with the exception of the deepest sample at 110.71 mbsf, where the yield was $334 \mathrm{ppb}$ (Fig. 6). Methane is the dominant hydrocarbon present throughout ( 81 to $91 \mathrm{hc} \%$ ) and ethane, propane, and butane are minor components $(<16 \mathrm{ppb})$. Again, the deepest interval is exceptional in that the $\mathrm{C}_{2+}$ concentration exceeds $100 \mathrm{ppb}$. Neither the change in lithology at 56.4 mbsf from an upwelling facies to more terrestrially influenced sediments, nor the very low biogenic methane concentrations (monitored by the free-gas, Shipboard Scientific Party, 1988b) are reflected by the sorbed hydrocarbon gases. Bacterial methane is absent at Site 680 because of the presence of dissolved sulfate throughout the hole. Sulfate has a minimum of $6 \mathrm{mM}$ at $47.5 \mathrm{mbsf}$, but increases again at greater depths to $37.9 \mathrm{mM}$ due to replenishment of sulfate by the saline brine (see Shipboard Scientific Party, 1988b).

The $\delta^{13} \mathrm{C}_{\mathrm{CH}_{4}}$ is constrained between -39.9 and $-34.2 \%$, with molecular ratios $C_{1} /\left(C_{2}+C_{3}\right)$ of 4.6 to 17.7 (Fig. 3). As is the case for Site 679 , these gas signatures indicate a thermogenic source as shown in Figure 3, although the $\delta^{13} \mathrm{C}_{\mathrm{CH}_{4}}$ values are slightly more enriched in ${ }^{13} \mathrm{C}$ than those commonly expected for thermogenic gases.

At the companion Site 681, the interstitial chloride-depth gradient is slightly higher than at Site 680 . Despite the replenishment of sulfate from the brines at greater depth, the rate of sulfate uptake by the SRB is sufficient at Site 681 to establish a sulfate-free zone between 32 and 56 mbsf (Shipboard Scientific Party, 1988b), which corresponds to the position of the sulfate-minimum zone at Site 680 . Sulfate exhaustion at Site 681 and not at Site 680 cannot be explained by $\mathrm{C}_{\text {org }}$ contents, which are higher at Site 680 (2.2\% and $6.8 \%$, respectively), nor by the salinity gradient. A consequence of this difference in remineralization is the formation of bacterial gases at Site 681 and not at Site 680 , as seen in the free-gas distributions (Shipboard Scientific Party, 1988b). The single sample taken from 45.37 mbsf at Site 681 also has elevated amounts of sorbed $\mathrm{C}_{2}$. hydrocarbons at $77 \mathrm{ppb}$ and $\mathrm{a}_{1} /$ $\left(\mathrm{C}_{2}+\mathrm{C}_{3}\right)$ ratio of 7.7 (Table 1), similar to the thermogenic hydrocarbons at Site 680 . In contrast with values at Site 680 , the $\delta^{13} \mathrm{C}_{\mathrm{CH}_{4}}$ value of $-68.3 \%$ at Site 681 clearly indicates the influence of bacterial gas.

\section{Site 682}

Site 682 has the most consistent distribution of sorbed hydrocarbon gases. Uniformity is also characteristic of the geochemical environment of all the middle-slope sites drilled during Leg 112, including Site 682. The sediments do not contain hypersaline fluids, and in the Quaternary and uppermost Pliocene sediments, dissolved sulfate concentrations decrease rapidly at quite shallow depths below the seafloor $(<50 \mathrm{~m})$ to undetectable levels. These characteristics, i.e., the absence of both hypersaline brines and dissolved sulfate, strongly contrast with the sedimentary environments at Sites 679 and 680 and markedly influence the sorbed- and free-gas geochemistry.

Methanogenesis is active at Site 682, generating sufficient interstitial methane for the formation of gas hydrates (Kven- 

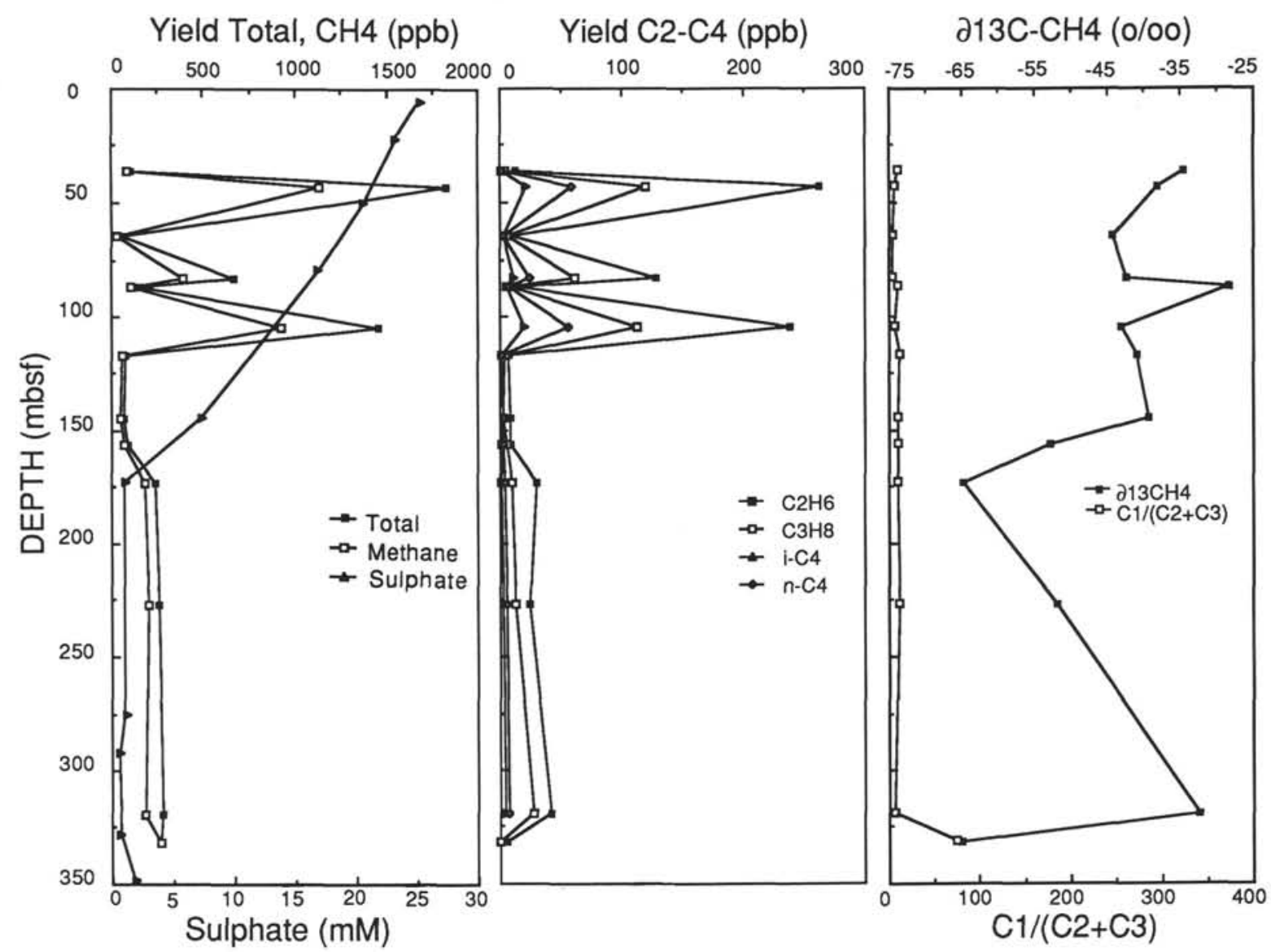

Figure 5. Molecular and isotope data of sorbed gases and dissolved sulfate from Site 679.

volden and Kastner, this volume). Sorbed-gas yields are higher here ( 464 to $1880 \mathrm{ppb}$, Fig. 7) than at the previous two sites and have a significantly greater methane component $(>98 \mathrm{hc} \%)$. Ethane and propane concentrations are low, and range from only 5 to $18 \mathrm{ppb}$ and 2 to $13 \mathrm{ppb}$, respectively, accounting for most of the $\mathrm{C}_{2+}$ component.

One sample (112-682A-36X, CC), however, has high ethane and propane contents and a most unusual preference of $C_{3}$ over $C_{2}$ by $200 \%$. This, along with the relatively negative $\delta^{13} \mathrm{C}_{\mathrm{CH}_{4}}$ and $\delta^{13} \mathrm{C}_{\mathrm{C}_{2} \mathrm{H}_{6}}$ values, indicates to us that the sample is probably artificial and contaminated. These data are reported in Figure 7 and Table 1, although we do not consider these in further discussions.

The dominance of biogenic methane throughout the hole is shown by the higher $C_{1} /\left(C_{2}+C_{3}\right)$ ratios (up to 302) and carbon isotope composition (Figs. 3 and 4 ). In all the samples at Site 682 , the methane is strongly depleted in ${ }^{13} \mathrm{C}$, a clear carbon isotope signature for bacterial methane. The $\delta^{13} \mathrm{C}_{\mathrm{CH}_{4}}$ is about $-72 \%$ at 108 to $120 \mathrm{mbsf}$; then, farther downhole, methane gradually becomes enriched in ${ }^{13} \mathrm{C}$, with a maximum $\delta^{13} \mathrm{C}_{\mathrm{CH}_{4}}$ value of $-63.1 \%$ at $352.24 \mathrm{mbsf}$. This shift in $\delta^{13} \mathrm{C}_{\mathrm{CH}_{4}}$ tracks the depletion of ${ }^{12} \mathrm{C}$ in the dissolved $\Sigma \mathrm{CO}_{2}$ by the methanogens $\left(\delta^{13} \mathrm{CO}_{2}\right.$ data from Claypool, pers. comm., 1989). The magnitude of the carbon isotope fractionation $\left(\alpha_{\mathrm{CO}_{2}-\mathrm{CH}_{4}}\right)$ between $\delta^{13} \mathrm{C}_{\mathrm{CO}_{2}}$ and $\delta^{13} \mathrm{C}_{\mathrm{CH}_{4}}$ is constant at about 1.07 and 1.08 (note: $\alpha_{\mathrm{CO}_{2}-\mathrm{CH}_{4}}=\left[\delta^{13} \mathrm{C}_{\mathrm{CO}_{2}}+10^{3}\right] /\left[\delta^{13} \mathrm{C}_{\mathrm{CH}_{4}}\right.$ $\left.\left.+10^{3}\right]\right)$.

In addition to this carbon isotope evidence, the $\delta \mathrm{D}_{\mathrm{CH}_{4}}$ values of -191 to $-202 \%$ (Fig. 4) also indicate that this methane is produced by the bacterial $\mathrm{CO}_{2}$-reduction pathway (Whiticar et al., 1986), typical for such marine environments.
The agreement of the isotope signatures and the absence of $\mathrm{C}_{2+}$ hydrocarbons suggests that the sorbed methane at this site, which is devoid of hypersaline pore fluids, corresponds to the prevailing chemical environment of bacterial methanogenesis, with no apparent influx of thermogenic hydrocarbons.

\section{Site 684}

The sorbed-gas concentration at Site 684 first increases gradually (total hc yield $<300 \mathrm{ppb}$ ) to a depth of $55 \mathrm{~m}$, below which the yields increase sharply and remain constant around $900 \mathrm{ppb}$ (Fig. 8). This increase coincides with the disappearance of dissolved sulfate and the accompanying profuse production of microbial methane. However, the sorbed-gas fraction has a characteristic high content of $\mathrm{C}_{2+}$ hydrocarbons (39 to $170 \mathrm{ppb}$ ). This is evident in the very low $C_{1} /\left(C_{2}+C_{3}\right)$ ratios. Both observations were noted during shipboard monitoring for safety (Shipboard Scientific Party, 1988c).

Pore fluids at Site 684 show the steepest increase in salinity of all shelf sites. At 100 mbsf, twice the normal seawater chlorinity was measured. Again, we suspect an association between high salinity fluids and higher concentrations of $\mathrm{C}_{2+}$ hydrocarbons. The same association is also seen in the deepest sediment sample at Site 680 and in some of the Quaternary/Pliocene samples at Site 679. The sulfatefree section of Site 684 (>40 mbsf), is dominated by microbial methanogenesis. The $\delta^{13} \mathrm{C}_{\mathrm{CH}_{4}}$ values of -76 to $-79 \%$ also indicate the presence of a biogenic gas with generally the same affinity as observed at Site 682 . The thermogenic signature observed in the $\delta^{13} \mathrm{C}_{\mathrm{CH}_{4}}$ values of the other saline sites is not seen in Site 684 , possibly owing to masking of 


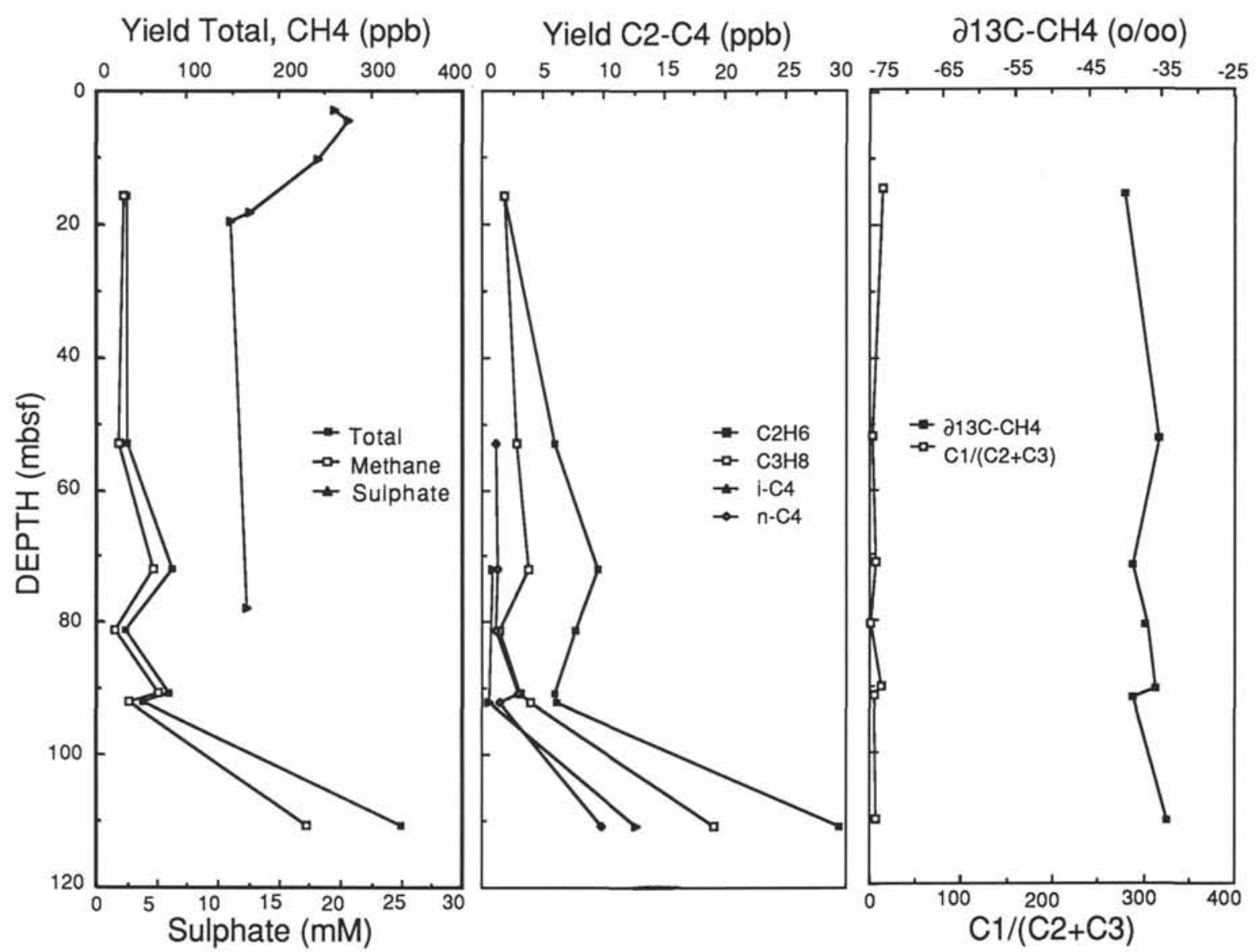

Figure 6. Molecular and isotope data of sorbed gases and dissolved sulfate from Site 680 .

bacterial methane. Only in the upper section of Site 684 , which contains dissolved sulfate and no methanogenesis, do the $\delta^{13} \mathrm{C}_{\mathrm{CH}_{4}}$ values of two samples $\left(\delta^{13} \mathrm{C}_{\mathrm{CH}_{4}},-58\right.$ and $-48 \%$ o $)$ deviate significantly from the character of a bacterial gas and approach the signature of a thermal gas (Fig. 3). The interpretation of these more shallow samples remains ambiguous because we have shown elsewhere that ${ }^{13} \mathrm{C}$-enriched methane may be generated by isotopic fractionation associated with microbial consumption of the original bacterial methane pool (Whiticar and Faber, 1986; Suess and Whiticar, 1989).

\section{Sites $\mathbf{6 8 6 / 6 8 7}$}

The distribution and character of the hydrocarbon gases at Sites 686 and 687 are strongly constrained by diagenetic processes. Organic carbon contents generally range from $1 \%$ to $3 \%$ at Site 686 , with higher levels in the uppermost 15 mbsf ( $4 \%$ to $5 \%$ ). Organic carbon contents up to $6 \%$ are measured at Site 687 . Consequently, dissolved sulfate is rapidly depleted, with complete removal occurring below 13 and 35 mbsf for Sites 686 and 687, respectively. Hypersaline fluids are present at Site 686; however, the salinity gradient is much lower, compared with the more northerly sites, and has a more diminished influence on the diagenesis. The sulfate replenishment associated with the brine is insufficient to match the bacterial utilization of sulfate.

Total hydrocarbon yields of sorbed-gases at Site 686 are low in the sulfate zone ( 25 to $68 \mathrm{ppb}$ ). Where the dissolved sulfate has been exhausted, the total hydrocarbon yield in- creases steadily, up to a maximum value of $2480 \mathrm{ppb}$ at 220.50 mbsf (Fig. 9). Methane constitutes more than 99 hc\%, with the exception of the samples in the uppermost $25 \mathrm{mbsf}$ and at $262.25 \mathrm{mbsf}$. The bacterial source of the methane is confirmed by the combination of the molecular and carbon and hydrogen isotope data (Figs. 3 and 4). At depths greater than 50 mbsf, the $\delta^{13} \mathrm{C}_{\mathrm{CH}_{4}}$ values vary around $-65 \%$ o (Fig. 9). A minimum $\delta^{13} \mathrm{C}_{\mathrm{CH}_{4}}$ value of $-69.8 \%$ is recorded at $48.75 \mathrm{mbsf}$, near the depth for the onset of methanogenesis. The $\delta \mathrm{D}_{\mathrm{CH}_{4}}$ values range from -175 to $-195 \%$ within this depth interval. These data indicate that, as at Sites 682 and 684 , the methanogenic pathway is bacterial $\mathrm{CO}_{2}$-reduction (Fig. 4; Whiticar et al., 1986).

A similar gas geochemical situation is found at Site 687. The methane yields at Site 687 varied from $9 \mathrm{ppb}(86.5 \mathrm{hc} \%)$ near the surface at $2.98 \mathrm{mbsf}$, to $801 \mathrm{ppb}(99.0 \mathrm{hc} \%)$ at 75.78 mbsf (Fig. 10). The three deepest samples have a clear bacterial carbon-isotope signature $\left(\delta^{13} \mathrm{C}_{\mathrm{CH}_{4}}\right.$ is -75.6 to $-65.4 \%$ ), whereas the shallowest two samples indicate signs of anaerobic methane oxidation as found at Site 686.

In the sulfate zones of Sites 686 and 687 , similar to the zone at Site 684, anaerobic methane oxidation is responsible for the shifts in $\delta^{13} \mathrm{C}_{\mathrm{CH}_{4}}$ to heavier values of -52.0 to $-41.3 \%$ at Site 686 and -38.3 to $-33.2 \%$ at Site 687 , along with maintenance of the low methane concentrations. This preferential removal of methane, resulting in a relative increase in $\mathrm{C}_{2}$ hydrocarbons, is also shown by the shift in $\mathrm{C}_{1} /\left(\mathrm{C}_{2}+\mathrm{C}_{3}\right)$ from values $>100$ in the methane production zone to values $<50$ in the methanotrophic zone (Fig. 9). Methane oxidation may also be 


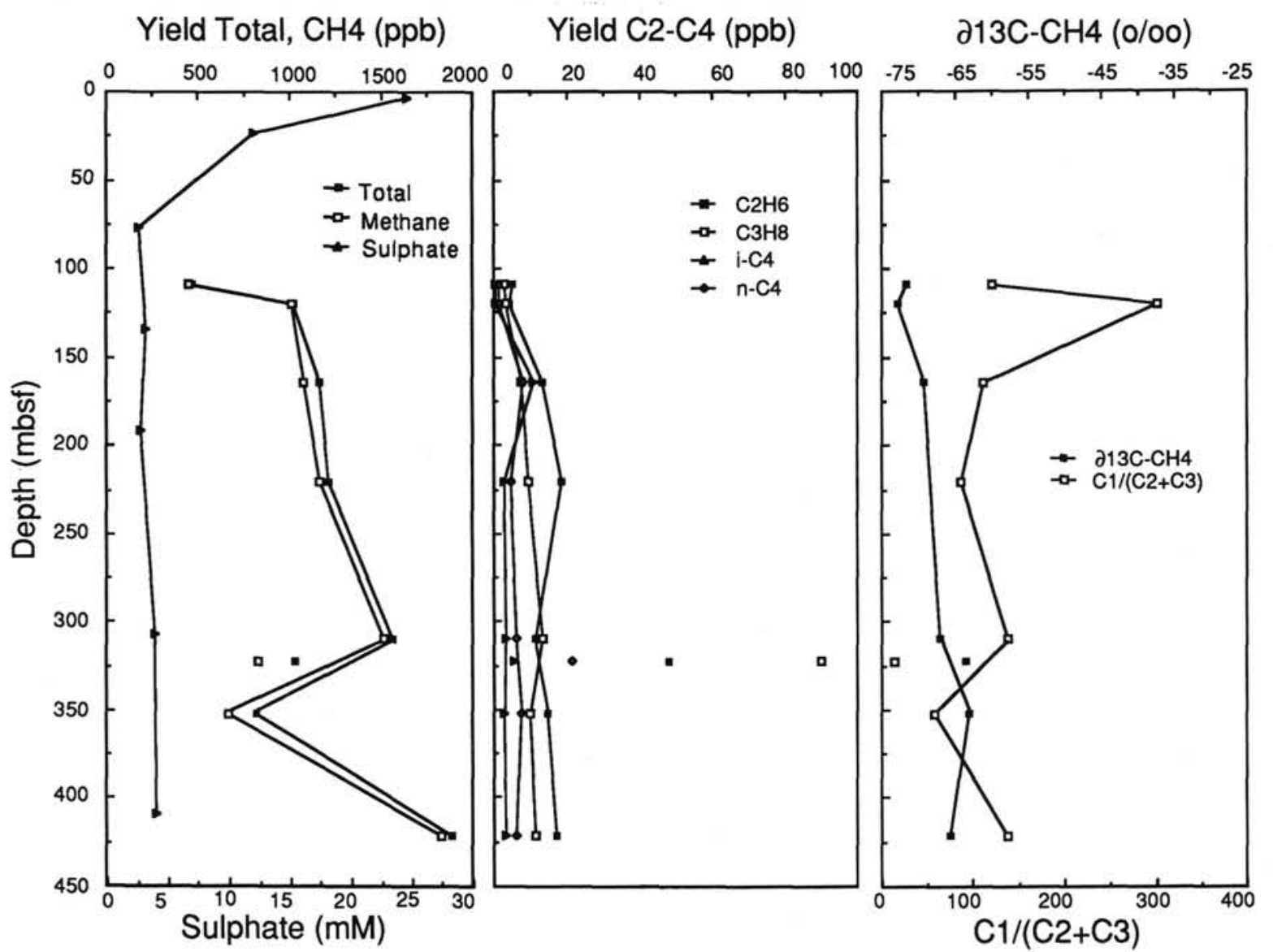

Figure 7. Molecular and isotope data of sorbed gases and dissolved sulfate from Site 682.

responsible for the somewhat heavier methane isotope ratios at $165.75 \mathrm{mbsf}$ at Site 686 .

The concentration of higher hydrocarbons in the sorbedgas fraction at Site 686 increases gradually with depth (Fig. 9). This increase in $\mathrm{C}_{2+}$ hydrocarbon is seen as a gradual shift $\mathrm{C}_{1} /\left(\mathrm{C}_{2}+\mathrm{C}_{3}\right)$ to lower values with depth. The $\mathrm{C}_{2+}$ hydrocarbon content of the sorbed-gases at 686 is also generally lower than at the other sites containing brines. However, the overall salinity increase at Site 686 is the smallest of all the shelf sites, e.g., only one-third as high as at Site 684 , so that perhaps we should not expect such a strong $\mathrm{C}_{2+}$ hydrocarbon signal. The sample at Section 112-686B-28X-5, at $262.25 \mathrm{mbsf}$, is an exception. There, the content of sorbed $\mathrm{C}_{2+}$ hydrocarbons ( 105 and $>100 \mathrm{ppb} \mathrm{C}_{5}$ ) is comparable to the higher $\mathrm{C}_{2+}$ content of the hypersaline samples at other sites. A thermogenic source for these higher hydrocarbons cannot be ruled out, although the methane carbon isotope signature is masked by the presence of bacterial gas.

In summary, we observe a dominance of microbial methane in the sorbed-gas fraction, and little evidence for $\mathrm{C}_{2+}$ hydrocarbons, which are seen at the other Peru shelf sites having elevated interstitial salinity. The gas distribution and character at the companion Site 687 (Figs. 10 and 3, Table 1), are similar to those observed for the sorbed hydrocarbons at Site 686.

\section{INTERPRETATION}

\section{Hydrocarbon Gas Types and Their Association with Hypersaline Fluids}

Geochemical analysis of the samples from Leg 112 identified bacterial hydrocarbon gas at Sites $681,682,684,686$, and
687 and thermogenic hydrocarbon gases at Sites $679,680,684$, and 686 .

The deep water Site 682 (3788 mbsf), which is more than $85 \mathrm{~km}$ distant from the shelf sites, provides an example of a "reference" sorbed hydrocarbon gas distribution, not influenced by hypersaline fluids. Bacterial methane is the dominant hydrocarbon type here, with low $\mathrm{C}_{2+}$ yields in both the free- and sorbed-gas fractions. The isotope signatures $\left(\delta^{13} \mathrm{C}_{\mathrm{CH}_{4}}\right.$ of -72 to $-63.1 \%$; $\delta \mathrm{D}_{\mathrm{CH}_{4}}$ of -191 to $-202 \%$ ) and molecular composition (i.e., $\mathrm{C}_{1} /\left[\mathrm{C}_{2}+\mathrm{C}_{3}\right]$ up to 302) confirm this bacterial gas interpretation. The absence of thermogenic gases at this site corresponds to the absence of subsurface brines.

The occurrence of sorbed $\mathrm{C}_{2+}$ hydrocarbons in the hypersaline shelf sediments (Sites $681,680,684$, and possibly Site 686), suggests that these hydrocarbons are associated with the presence or movement of these subsurface brines.

In the sulfate-containing zone of all hypersaline sites, the "heavy" carbon isotope signature of the sorbed methane could lead to an ambiguous interpretation. Used alone, this isotope criterion could indicate that the hydrocarbon gas type is either a thermogenic source, or a residual bacterial methane, i.e., methane remaining after the microbial oxidation of a bacterial gas pool (Whiticar and Faber, 1986; Suess and Whiticar, 1989). However, the additional information from the molecular (e.g., $\mathrm{C}_{2+}$ yields, $\mathrm{C}_{1} /\left(\mathrm{C}_{2}+\mathrm{C}_{3}\right)$ ratios) and isotope data, in concert, suggests that these gases indeed may have a thermogenic source. In other cases, these criteria reveal that some gases are strongly overprinted by bacterial methane.

Kastner et al. (this volume) suggest that the hypersaline fluids may have migrated southward, a considerable distance $(500 \mathrm{~km})$ along the shelf in the Salaverry Basin. We consider 

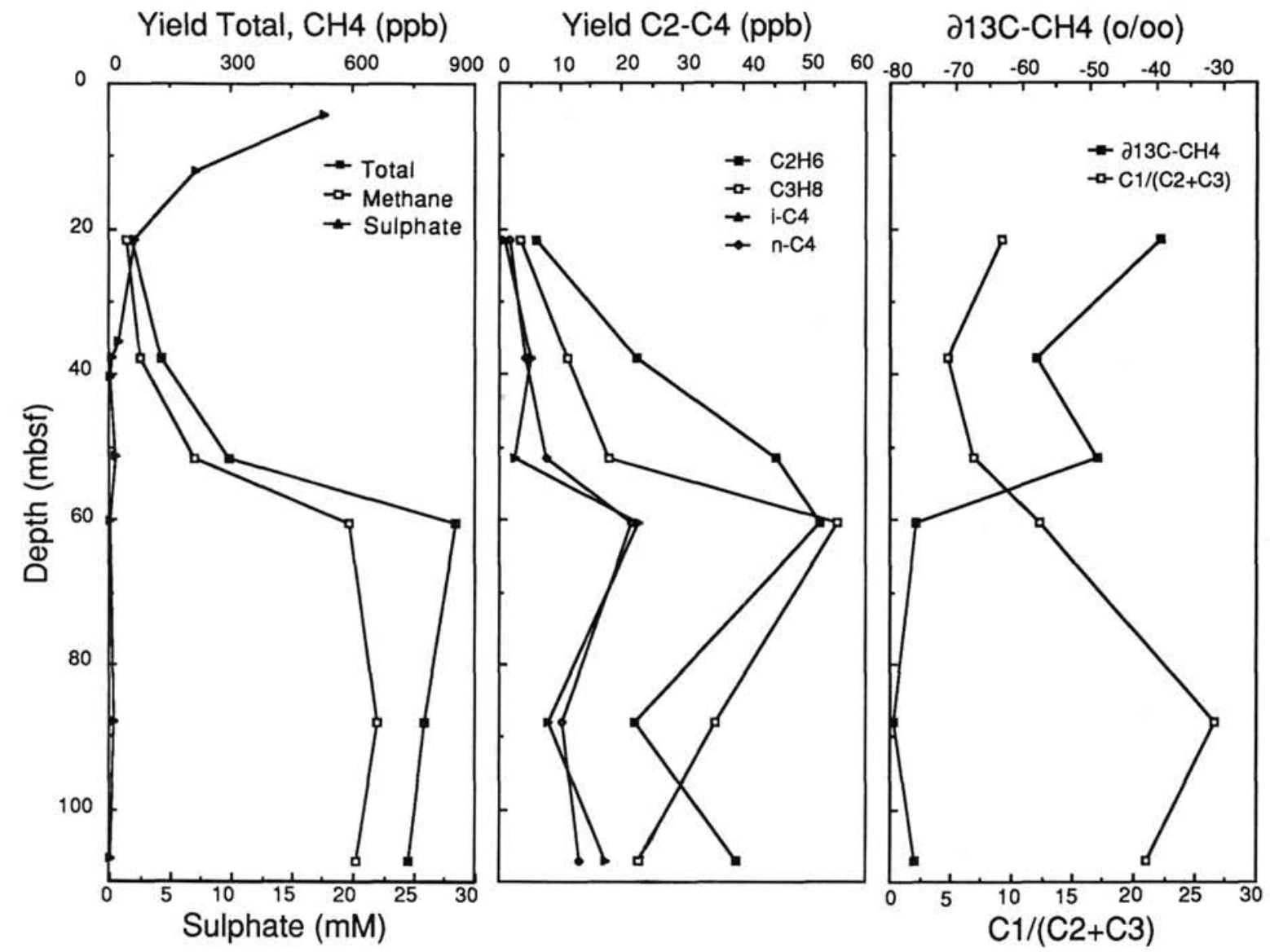

Figure 8. Molecular and isotope data of sorbed gases and dissolved sulfate from Site 684 .

it too speculative at this stage to discuss the connection between the brines and the thermogenic hydrocarbons, except to remark on the observed associations. Nevertheless, the following consideration of the $\mathrm{C}_{1}, \mathrm{C}_{2}$, and $\mathrm{C}_{3}$ carbon-isotope data may add further evidence for a thermogenic source for some of the sorbed-gases.

The $\delta^{13} \mathrm{C}_{\mathrm{CH}_{4}}, \delta^{13} \mathrm{C}_{\mathrm{C}_{2} \mathrm{H}_{6}}$, and $\delta^{13} \mathrm{C}_{\mathrm{C}_{3} \mathrm{H}_{8}}$ values measured on gases from Sites 679, 680, and 682 are plotted in Figure 11. Only a limited number of samples exist because the yields of ethane and propane were often insufficient to perform isotope measurements. Included in Figure 11, for comparison, are the sorbed-gas data pairs of Core 112-679D-5H, CC $(<63 \mu \mathrm{m}$ and $>63 \mu \mathrm{m}$ size fractions). The generalized carbon-isotope relationships $\left(\delta^{13} \mathrm{C}_{\mathrm{CH}_{4}}, \delta^{13} \mathrm{C}_{\mathrm{C}_{2} \mathrm{H}_{6}}\right.$, and $\left.\delta^{13} \mathrm{C}_{\mathrm{C}_{3} \mathrm{H}_{8}}\right)$ established between co-genetic pairs of methane, ethane, and propane of bona fide thermogenic gases (Type II kerogen) are also included. The equations defining these relationships were published by Faber (1987) and Faber and Whiticar (1989) and are as follows:

$$
\begin{aligned}
& \delta^{13} \mathrm{C}_{\mathrm{CH}_{4}}=0.68 \delta^{13} \mathrm{C}_{\mathrm{C}_{2} \mathrm{H}_{4}}-19.4 \text { methane-ethane, } \\
& \delta^{13} \mathrm{C}_{\mathrm{C}_{3} \mathrm{H}_{8}}=0.93 \delta^{13} \mathrm{C}_{\mathrm{C}_{2} \mathrm{H}_{6}}+0.055 \text { propane-ethane. }
\end{aligned}
$$

The $\delta^{13} \mathrm{C}_{\mathrm{C}_{2} \mathrm{H}_{6}}$ and $\delta^{13} \mathrm{C}_{\mathrm{C}_{3} \mathrm{H}_{8}}$ ratios of the gases at Sites 679 , 680 , and 682 fall along the propane-ethane line, indicating that the individual gas pairs are probably co-genetic and originate from a Type II kerogen. In contrast, many of the $\delta^{13} \mathrm{C}_{\mathrm{CH}_{4}}$, and $\delta^{13} \mathrm{C}_{\mathrm{C}_{2} \mathrm{H}_{6}}$ pairs of the gases at Sites 679,680 , and 682 deviate from the expected relationship of the methane-ethane line. Those gases failing below that line clearly show the admixture of bacterial methane (i.e., methane depleted in ${ }^{13} \mathrm{C}$ ). The methane and ethane isotope data further indicate that the other end-member of these gas mixtures lies near the generalized relationship, perhaps slightly above it. These gases, with methane preferentially enriched in ${ }^{13} \mathrm{C}$ relative to ethane, could indicate the influence of hydrocarbon gases from a Type III kerogen source.

The molecular and isotope compositions of the bacterial and thermogenic hydrocarbons at the sites influenced by the hypersaline fluids provide us with a plausible explanation for the occurrence of these same $\mathrm{C}_{2+}$ hydrocarbons between 45 and $82 \mathrm{mbsf}$ at Site 679 . Here, the hypersaline fluids are barred from reaching the deeper strata by a normally faulted structural ridge that separates the hypersaline Salaverry Basin from the normal, marine Lima Basin. The effectiveness of this deep migration barrier is shown by the juxtaposition of the hypersaline fluids at Site 680 with freshwaterinfluenced sediments at Site 679 , less than $10 \mathrm{~km}$ away. At Site 679 in the sediments above the barrier ( 45 and $82 \mathrm{mbsf}$ ), there is evidence that the hypersaline fluids are spilling over into the Lima Basin. It is in this depth interval that the high concentrations of $\mathrm{C}_{2+}$ hydrocarbons were measured. Again, the implication is that these $\mathrm{C}_{2+}$ hydrocarbons are causally related to the brine incursion.

\section{Estimates of Maturity}

The maturity of the organic matter responsible for generating the thermogenic hydrocarbons can be estimated on the basis of relationships established for Type II kerogen between 
Table 1. Molecular and isotope composition of sorbed gases.

\begin{tabular}{|c|c|c|c|c|c|c|c|c|c|c|c|c|c|c|c|c|c|c|c|c|c|c|c|c|c|c|c|c|}
\hline \multirow[b]{2}{*}{ Core, section } & \multirow[b]{2}{*}{$\begin{array}{l}\text { Depth } \\
\text { (mbsf) }\end{array}$} & \multicolumn{12}{|c|}{ Hydrocarbon yield ( $\mathrm{ppb}$ dry sediment $\mathrm{wt}$. basis) } & \multicolumn{9}{|c|}{ Hydrocarbon \% (vol. basis) } & \multirow[b]{2}{*}{$\mathrm{C}_{2} / \mathrm{C}_{1}$} & \multirow{2}{*}{$\frac{c_{1}}{c_{2}+c_{3}}$} & \multirow[b]{2}{*}{$\begin{array}{l}\delta^{13} \mathrm{C}_{1} \\
\left(\mathrm{~F}_{00}\right)\end{array}$} & \multirow[b]{2}{*}{$\begin{array}{l}{ }^{\delta^{13} \mathrm{C}_{2}} \\
(\%(\%))^{2}\end{array}$} & \multirow[b]{2}{*}{ 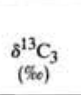 } & \multirow[b]{2}{*}{$\underset{\left({ }_{(c e)}\right.}{\delta D-C_{1}}$} \\
\hline & & $\mathrm{CH}_{4}$ & $\mathrm{C}_{2} \mathrm{H}_{4}$ & $\mathrm{C}_{2} \mathrm{H}_{6}$ & $\mathrm{C}_{3} \mathrm{H}_{6}$ & $\mathrm{C}_{3} \mathrm{H}_{8}$ & $i \cdot \mathrm{C}_{4}$ & $\begin{array}{l}n- \\
\mathrm{C}_{4}\end{array}$ & $\mathrm{C}_{2} \mathrm{H}_{10}$ & $i-\mathrm{C}_{5}$ & $\begin{array}{l}n- \\
\mathrm{C}_{5}\end{array}$ & $\mathrm{C}_{5} \mathrm{H}_{12}$ & $\begin{array}{l}\text { Total } \\
C_{1} / C_{5}\end{array}$ & $\mathrm{CH}_{4}$ & $\mathrm{C}_{2} \mathrm{H}_{4}$ & $\mathrm{C}_{2} \mathrm{H}_{6}$ & $\mathrm{C}_{3} \mathrm{H}_{6}$ & $\mathrm{C}_{3} \mathrm{H}_{8}$ & $\begin{array}{l}i \cdot{ }_{4} \\
\mathrm{C}_{4}\end{array}$ & $\begin{array}{l}n- \\
\mathrm{c}_{4}\end{array}$ & $\begin{array}{l}i . \\
c_{5}\end{array}$ & $n \cdot C_{5}$ & & & & & & \\
\hline $112-679 \mathrm{D}-4 \mathrm{H}, \mathrm{CC}$ & 36.11 & 84 & 0.0 & 12.3 & 0.0 & 4.2 & 2.1 & 1.7 & 3.8 & & 0.8 & & 108 & 90.0 & 0.0 & 7.0 & 0.0 & 1.6 & 0.6 & 0.5 & & 0.2 & & 10.4 & -34.5 & -26.4 & & \\
\hline $679 \mathrm{D}-5 \mathrm{H}, \mathrm{CC}$ & 42.85 & 1130 & 15.2 & 262.6 & 0.0 & 118.7 & 21.7 & 58.2 & 78.8 & 37.8 & 32.4 & 70.4 & 1828 & 83.1 & 0.6 & 10.3 & 0.0 & 3.2 & 0.4 & 1.2 & 0.6 & 0.5 & 0.12 & 6.2 & -38.1 & -27.9 & -26.4 & -198.0 \\
\hline $678 \mathrm{D}-7 \mathrm{H}$ & 64.61 & 26 & 0.0 & 10.3 & 0.0 & 5.8 & 3.2 & 2.3 & 5.5 & & & . & 53 & 74.0 & 0.0 & 15.6 & 0.0 & 6.1 & 2.5 & 1.8 & 0.0 & 0.5 & 0.21 & 3.4 & -44.4 & -31.4 & 20.4 & -150.0 \\
\hline $678 \mathrm{D}-8 \mathrm{H}, \mathrm{CC}$ & 82.84 & 384 & 2.5 & 128.2 & 0.0 & 61.3 & 11.0 & 24.7 & 35.7 & & 3.6 & & 662 & 79.2 & 0.3 & 13.9 & 0.0 & 4.5 & 0.6 & 1.4 & & 0.2 & 0.18 & 4.3 & -42.3 & -29.2 & -26.5 & -216.0 \\
\hline $678 \mathrm{D}-10 \mathrm{H}, \mathrm{CC}$ & 86.62 & 106 & 0.0 & 14.4 & 0.0 & 8.5 & 5.2 & 7.7 & 12.8 & & 1.4 & & 156 & 87.9 & 0.0 & 6.4 & 0.0 & 2.6 & 1.2 & 1.8 & & 0.3 & 0.07 & 9.8 & -28.3 & -32.3 & -30.7 & \\
\hline $678 \mathrm{D}-12 \mathrm{H}, \mathrm{CC}$ & 104.30 & 823 & 10.6 & 238.1 & 2.8 & 113.1 & 20.0 & 55.4 & 75.3 & & 18.7 & & 1458 & 82.2 & 0.5 & 11.3 & 0.1 & 3.7 & 0.5 & 1.4 & & 0.4 & 0.14 & 5.5 & -43.2 & -28.0 & -27.9 & -200.0 \\
\hline 678D-14X & $\begin{array}{l}116.75 \\
14460\end{array}$ & $\begin{array}{l}58 \\
48\end{array}$ & 0.0 & $\begin{array}{l}7.0 \\
8.3\end{array}$ & 0.0 & 3.6 & 1.4 & 1.8 & 3.3 & & 0.3 & & 76 & 90.8 & 0.0 & 5.8 & 0.0 & 2.0 & 0.6 & 0.8 & & 0.1 & 0.06 & 11.7 & -41.0 & -30.8 & & \\
\hline $\begin{array}{l}678 \mathrm{D}-17 \mathrm{X}, \mathrm{CC} \\
678 \mathrm{D}-18 \mathrm{X}, \mathrm{CC}\end{array}$ & $\begin{array}{l}144.60 \\
155.88\end{array}$ & $\begin{array}{l}48 \\
65\end{array}$ & $\begin{array}{l}0.0 \\
0.8\end{array}$ & $\begin{array}{l}8.3 \\
8.2\end{array}$ & $\begin{array}{l}0.0 \\
0.0\end{array}$ & $\begin{array}{l}3.1 \\
5.0\end{array}$ & $\begin{array}{l}2.3 \\
1.3\end{array}$ & $\begin{array}{l}2.3 \\
2.8\end{array}$ & $\begin{array}{l}4.6 \\
4.1\end{array}$ & & $\begin{array}{l}1.8 \\
1.0\end{array}$ & & $\begin{array}{l}71 \\
88\end{array}$ & $\begin{array}{l}87.2 \\
88.4\end{array}$ & 0.0 & 7.9 & 0.0 & 2.0 & 1.1 & 1.1 & & 0.7 & 0.09 & 8.9 & $\begin{array}{l}-39.4 \\
-52.8\end{array}$ & -26.2 & & \\
\hline $\begin{array}{l}678 \mathrm{D}-218 \mathrm{X}, \mathrm{CC} \\
6 \mathrm{D}-\mathrm{CC}\end{array}$ & $\begin{array}{l}173.88 \\
172.82\end{array}$ & $\begin{array}{l}03 \\
182\end{array}$ & $\begin{array}{l}0.8 \\
0.0\end{array}$ & $\begin{array}{l}8.2 \\
28.6\end{array}$ & 0.0 & 8.4 & $\begin{array}{l}1.3 \\
1.0\end{array}$ & $\begin{array}{l}2.8 \\
4.5\end{array}$ & $\begin{array}{l}4.1 \\
6.4\end{array}$ & & $\begin{array}{l}1.0 \\
0.5\end{array}$ & & $\begin{array}{r}88 \\
234\end{array}$ & $\begin{array}{l}88.4 \\
89.6\end{array}$ & $\begin{array}{l}0.6 \\
0.0\end{array}$ & $\begin{array}{l}6.7 \\
7.8\end{array}$ & $\begin{array}{l}0.0 \\
0.0\end{array}$ & $\begin{array}{l}2.5 \\
1.7\end{array}$ & $\begin{array}{l}0.5 \\
0.3\end{array}$ & $\begin{array}{l}1.1 \\
0.6\end{array}$ & & 0.3 & $\begin{array}{l}0.08 \\
0.09\end{array}$ & $\begin{array}{l}9.7 \\
9.5\end{array}$ & $\begin{array}{l}-52.8 \\
-64.7\end{array}$ & $\begin{array}{l}-33.1 \\
-27.9\end{array}$ & & \\
\hline $679 \mathrm{D}-26 \mathrm{X}$ & 227.21 & 201 & 1.0 & 24.5 & 0.0 & 13.0 & 2.6 & 5.0 & 7.5 & & & & 255 & 90.8 & 0.3 & 5.9 & 0.0 & 2.1 & 0.3 & 0.6 & & 0.1 & 0.07 & $\begin{array}{r}9.3 \\
11.3\end{array}$ & $\begin{array}{l}-50.7 \\
-51.8\end{array}$ & $\begin{array}{l}-27.9 \\
-27.3\end{array}$ & & \\
\hline $678 \mathrm{E}-8 \mathrm{X}, \mathrm{CC}$ & 318.50 & 183 & 2.3 & 41.5 & 0.0 & 27.3 & 4.5 & 7.5 & 12.0 & & 1.3 & & 278 & 83.2 & 0.6 & 10.1 & 0.0 & 4.5 & 0.6 & 0.9 & & 0.1 & 0.12 & 5.7 & -32.4 & -25.8 & -24.6 & \\
\hline 679E-10X, CC & $\begin{array}{r}331.69 \\
15.75\end{array}$ & 262 & 0.0 & 6.2 & 0.0 & 0.7 & & & & & & & 269 & 98.7 & 0.0 & 1.2 & 0.0 & 0.1 & & & & & 0.01 & 73.6 & -64.9 & -48.3 & & \\
\hline $680 \mathrm{~B}-3 \mathrm{H}-1$ & $\begin{array}{l}15.75 \\
53.08\end{array}$ & $\begin{array}{l}30 \\
25\end{array}$ & $\begin{array}{l}0.0 \\
0.0\end{array}$ & $\begin{array}{l}1.9 \\
6.9\end{array}$ & 0.0 & 1.9 & & & & & & & 34 & 94.7 & 0.0 & 3.2 & 0.0 & 2.2 & & & & & 0.03 & 17.7 & $\begin{array}{l}-39.9 \\
-39\end{array}$ & & & \\
\hline $\begin{array}{l}680 \mathrm{~B}-6 \mathrm{H}, \mathrm{CC} \\
680 \mathrm{~B}-8 \mathrm{H}, \mathrm{CC}\end{array}$ & $\begin{array}{l}53.08 \\
72.11\end{array}$ & $\begin{array}{l}25 \\
64\end{array}$ & $\begin{array}{l}0.0 \\
2.5\end{array}$ & $\begin{array}{l}6.0 \\
9.6\end{array}$ & 0.0 & $\begin{array}{l}2.9 \\
3.8\end{array}$ & 0.8 & $\begin{array}{l}1.1 \\
1.3\end{array}$ & 2.1 & & & & $\begin{array}{l}35 \\
84\end{array}$ & $\begin{array}{l}84.6 \\
88.2\end{array}$ & $\begin{array}{l}0.0 \\
2.0\end{array}$ & 10.8 & 0.0 & 3.6 & & $\begin{array}{l}1.0 \\
0.5\end{array}$ & & & 0.13 & 5.9 & $\begin{array}{l}-35.1 \\
-38.8\end{array}$ & -28.4 & & \\
\hline $680 \mathrm{~B}-9 \mathrm{H}, \mathrm{CC}$ & 81.19 & 22 & 0.0 & $\begin{array}{l}9.6 \\
7.7\end{array}$ & & $\begin{array}{l}3.8 \\
1.5\end{array}$ & & 1.1 & 2.1 & & & & $\begin{array}{l}84 \\
32\end{array}$ & $\begin{array}{l}88.2 \\
81.3\end{array}$ & $\begin{array}{l}2.0 \\
0.0\end{array}$ & $\begin{array}{l}7.1 \\
15.5\end{array}$ & & $\begin{array}{l}1.9 \\
2.0\end{array}$ & 0.3 & $\begin{array}{l}0.5 \\
1.2\end{array}$ & & & $\begin{array}{l}0.08 \\
0.19\end{array}$ & $\begin{array}{l}9.8 \\
4.6\end{array}$ & $\begin{array}{l}-38.8 \\
-36.7\end{array}$ & -28.4 & & \\
\hline $680 \mathrm{~B}-10 \mathrm{H}, \mathrm{CC}$ & 90.70 & 68 & 0.0 & 6.0 & & 3.1 & & 3.0 & & & & & 80 & 93.0 & 0.0 & 4.4 & & 1.5 & & 1.1 & & & 0.05 & 15.8 & -35.8 & -29.4 & & \\
\hline $680 \mathrm{~B}-12 \mathrm{X}, \mathrm{CC}$ & 92.02 & 36 & 0.0 & 6.2 & & 4.0 & 0.6 & 1.5 & 2.1 & & 0.2 & & 51 & 87.0 & 0.0 & 7.9 & & 3.5 . & 0.4 & 1.0 & & 0.1 & 0.09 & 7.6 & -38.8 & -29.3 & & \\
\hline $680 \mathrm{~B}-14 \mathrm{X}, \mathrm{CC}$ & 110.71 & 230 & 0.0 & 29.4 & & 19.1 & 12.7 & 9.9 & 22.6 & & 10.0 & & 334 & 88.1 & 0.0 & 6.0 & & $2.7^{\circ}$ & 1.3 & 1.1 & & 0.9 & 0.07 & 10.2 & -34.2 & -28.2 & -25.1 & \\
\hline $681 \mathrm{C}-6 \mathrm{H}-1$ & $\begin{array}{r}45.37 \\
\end{array}$ & 122 & 0.0 & 20.6 & 0.0 & 13.3 & 5.0 & 5.1 & 10.1 & 10.8 & 0.6 & 11.5 & 199 & 85.2 & 0.0 & 7.7 & 0.0 & 3.4 & 1.0 & 1.0 & 1.7 & 0.1 & 0.09 & 7.7 & -68.3 & & & \\
\hline $\begin{array}{l}682 \mathrm{~A}-12 \mathrm{XX}, \mathrm{CC} \\
68 \mathrm{~A}-13 \mathrm{CC}\end{array}$ & $\begin{array}{l}108.45 \\
119.67\end{array}$ & $\begin{array}{r}452 \\
1006\end{array}$ & & $\begin{array}{l}5.1 \\
4.2\end{array}$ & & $\begin{array}{l}2.8 \\
3.1\end{array}$ & $\begin{array}{l}0.7 \\
0.7\end{array}$ & $\begin{array}{l}1.5 \\
1.5\end{array}$ & $\begin{array}{l}2.2 \\
2.2\end{array}$ & & & & $\begin{array}{r}464 \\
1018\end{array}$ & $\begin{array}{l}99.1 \\
99.6\end{array}$ & & $\begin{array}{l}0.6 \\
0.2\end{array}$ & & $\begin{array}{l}0.2 \\
0.1\end{array}$ & $\begin{array}{l}0.0 \\
0.0\end{array}$ & $\begin{array}{l}0.1 \\
0.0\end{array}$ & & & $\begin{array}{l}0.01 \\
0.00\end{array}$ & $\begin{array}{l}120.8 \\
301.8\end{array}$ & $\begin{array}{l}-71.6 \\
-72.9\end{array}$ & & & $\begin{array}{l}-198.0 \\
-193.0\end{array}$ \\
\hline 682A-18X, CC & 164.35 & 1075 & 0.0 & 13.1 & 0.0 & 7.5 & 11.1 & 8.3 & 19.4 & 8.4 & 3.4 & 11.8 & $\begin{array}{l}1158 \\
1158\end{array}$ & 98.4 & 0.0 & 0.6 & 0.0 & 0.3 & 0.3 & 0.2 & 0.2 & 0.1 & 0.01 & 110.5 & -69.3 & -32.5 & & -202.0 \\
\hline $682 \mathrm{~A}-24 \mathrm{X}, \mathrm{CC}$ & 220.21 & 1160 & 0.8 & 18.8 & & 9.7 & 3.0 & 4.7 & 7.7 & & 1.6 & & 1206 & 98.6 & 0.0 & 0.9 & & 0.3 & 0.1 & 0.1 & & 0.0 & 0.01 & 85.7 & & & & 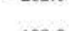 \\
\hline $682 \mathrm{~A}-34 \mathrm{X}, \mathrm{CC}$ & 309.49 & 1512 & 2.9 & 11.5 & & 13.4 & 3.3 & 6.1 & 9.4 & & 2.8 & & 1561 & 99.0 & 0.1 & 0.4 & & 0.3 & 0.1 & 0.1 & & 0.0 & 0.00 & 137.4 & -67.1 & & & -198.0 \\
\hline $682 \mathrm{~A}-36 \mathrm{X}, \mathrm{CC}$ & 322.23 & 828 & 2.8 & 48.0 & & 89.9 & 5.5 & 21.4 & 27.0 & & 2.0 & & 1025 & 92.4 & 0.2 & 2.9 & & 3.7 & 0.2 & 0.7 & & 0.1 & & 14.2 & -63.5 & -37.9 & -32.5 & \\
\hline $682 \mathrm{~A}-39 \mathrm{X}, \mathrm{CC}$ & 352.24 & 668 & 1.6 & 15.0 & 0.5 & 10.0 & 2.7 & 7.7 & 10.4 & 4.0 & 48.7 & 52.7 & 821 & 97.5 & 0.1 & 1.2 & 0.0 & 0.5 & 0.1 & 0.3 & 0.1 & 1.6 & & 57.4 & & -31.1 & & -191.0 \\
\hline $682 \mathrm{~A}-47 \mathrm{X}, \mathrm{CC}$ & 421.63 & 1831 & 1.6 & 17.3 & & 11.2 & 3.4 & 6.0 & 9.4 & & 1.7 & & $\begin{array}{r}1882 \\
56\end{array}$ & $\begin{array}{l}99.1 \\
88.7\end{array}$ & 0.1 & 0.5 & & 0.2 & 0.1 & 0.1 & & 0.0 & 0.01 & 137.6 & $\begin{array}{l}-65.6 \\
-303\end{array}$ & -34.8 & -30.4 & -198.0 \\
\hline $\begin{array}{l}6844-3 \mathrm{H}-3 \\
68 \mathrm{C}-5 \mathrm{H}-1\end{array}$ & $\begin{array}{l}21.48 \\
37.78\end{array}$ & $\begin{array}{l}41 \\
75\end{array}$ & $\begin{array}{l}0.0 \\
0.8\end{array}$ & $\begin{array}{r}6.1 \\
22.5\end{array}$ & $\begin{array}{l}0.0 \\
6.2\end{array}$ & $\begin{array}{r}3.5 \\
11.2\end{array}$ & $\begin{array}{l}0.8 \\
5.0\end{array}$ & $\begin{array}{l}1.8 \\
4.3\end{array}$ & $\begin{array}{l}2.6 \\
9.3\end{array}$ & $\begin{array}{l}0.0 \\
0.0\end{array}$ & $\begin{array}{l}0.0 \\
0.5\end{array}$ & $\begin{array}{l}0.0 \\
0.5\end{array}$ & $\begin{array}{r}56 \\
135\end{array}$ & $\begin{array}{l}88.7 \\
77.7\end{array}$ & 0.0 & $\begin{array}{r}7.0 \\
12.4\end{array}$ & $\begin{array}{l}0.0 \\
2.4\end{array}$ & $\begin{array}{l}2.8 \\
4.2\end{array}$ & $\begin{array}{l}0.5 \\
1.4\end{array}$ & $\begin{array}{l}1.1 \\
1.2\end{array}$ & $\begin{array}{l}0.0 \\
0.0\end{array}$ & $\begin{array}{l}0.0 \\
0.1\end{array}$ & $\begin{array}{l}0.08 \\
0.16\end{array}$ & $\begin{array}{l}9.1 \\
4.7\end{array}$ & $\begin{array}{l}-39.3 \\
-58.1\end{array}$ & & & \\
\hline $\begin{array}{l}684 \mathrm{C}-5 \mathrm{H}-1 \\
684 \mathrm{C}-7 \mathrm{X}-2\end{array}$ & $\begin{array}{l}\begin{array}{l}37.78 \\
51.48\end{array} \\
\end{array}$ & $\begin{array}{r}75 \\
211\end{array}$ & $\begin{array}{l}0.8 \\
2.8\end{array}$ & $\begin{array}{l}22.5 \\
45.3\end{array}$ & $\begin{array}{l}6.2 \\
0.0\end{array}$ & $\begin{array}{l}11.2 \\
18.0\end{array}$ & $\begin{array}{l}5.0 \\
2.7\end{array}$ & $\begin{array}{l}4.3 \\
7.6\end{array}$ & $\begin{array}{c}9.3 \\
10.3\end{array}$ & $\begin{array}{l}0.0 \\
0.0\end{array}$ & $\begin{array}{l}0.5 \\
0.7\end{array}$ & $\begin{array}{l}0.5 \\
0.7\end{array}$ & $\begin{array}{l}135 \\
299\end{array}$ & $\begin{array}{l}77.7 \\
85.7\end{array}$ & $\begin{array}{l}0.5 \\
0.7\end{array}$ & $\begin{array}{l}12.4 \\
9.8\end{array}$ & $\begin{array}{l}2.4 \\
0.0\end{array}$ & $\begin{array}{l}4.2 \\
2.7\end{array}$ & $\begin{array}{l}1.4 \\
0.3\end{array}$ & $\begin{array}{l}1.2 \\
0.9\end{array}$ & $\begin{array}{l}0.0 \\
0.0\end{array}$ & $\begin{array}{l}0.1 \\
0.1\end{array}$ & $\begin{array}{l}0.16 \\
0.11\end{array}$ & $\begin{array}{l}4.7 \\
6.9\end{array}$ & $\begin{array}{l}-58.1 \\
-48.8\end{array}$ & & & \\
\hline $684 \mathrm{C}-8 \mathrm{XX}-2$ & 60.45 & 593 & 0.9 & 52.7 & 0.0 & 55.4 & 22.8 & 21.8 & 44.6 & 29.2 & 2.1 & 31.2 & 854 & 89.7 & 0.1 & 4.3 & 0.0 & 3.1 & 1.0 & 0.9 & $\begin{array}{l}0.0 \\
1.0\end{array}$ & 0.1 & 0.05 & $\begin{array}{l}0.9 \\
12.3\end{array}$ & $\begin{array}{l}-48.8 \\
-76.2\end{array}$ & & & \\
\hline & 87.98 & 659 & 0.0 & 22.2 & 3.5 & 35.4 & 8.0 & 10.3 & 18.3 & 10.6 & 1.2 & 11.8 & 780 & & 0.0 & 1.7 & 0.2 & 1.9 & 0.3 & 0.4 & 0.3 & 0.0 & & 26.6 & -79.4 & & & \\
\hline & 106.98 & 609 & 1.5 & 38.9 & 4.9 & 22.9 & 17.4 & 13.0 & 30.4 & 0.0 & 2.0 & 2.0 & 742 & 93. & 0.1 & 3.2 & 0.3 & 1.3 & 0.7 & 0.6 & 0.0 & 0.1 & & 21.0 & -76.3 & & & \\
\hline $686 \mathrm{~B}-1 \mathrm{H}-3$ & $\begin{array}{l}4.48 \\
9.58\end{array}$ & $\begin{array}{l}30 \\
52\end{array}$ & 1.2 & 2.9 & & 2.4 & 0.3 & 1.0 & ${ }_{2.8}^{1.3}$ & & & & $\begin{array}{l}39 \\
68\end{array}$ & $\begin{array}{l}89.7 \\
89.7\end{array}$ & 2.0 & $\begin{array}{l}4.6 \\
7.5\end{array}$ & & 2.7 & 0.3 & 0.8 & & & & 12.4 & -413 & & & \\
\hline $\begin{array}{l}686 \mathrm{~A} A-2 \mathrm{H} \cdot 3 \\
68 \mathrm{~A} \cdot 3 \mathrm{H}-3\end{array}$ & $\begin{array}{r}9.58 \\
19.08\end{array}$ & $\begin{array}{r}52 \\
249\end{array}$ & & $\begin{array}{l}8.1 \\
7.3\end{array}$ & & $\begin{array}{l}2.5 \\
3.2\end{array}$ & $\begin{array}{l}0.9 \\
0.7\end{array}$ & $\begin{array}{l}1.9 \\
2.0\end{array}$ & $\begin{array}{l}2.8 \\
2.8\end{array}$ & & & & $\begin{array}{r}68 \\
265\end{array}$ & $\begin{array}{l}89.7 \\
97.7\end{array}$ & & $\begin{array}{l}7.5 \\
1.5\end{array}$ & & $\begin{array}{l}1.6 \\
0.5\end{array}$ & $\begin{array}{l}0.4 \\
0.1\end{array}$ & 0.9 & & & & $\begin{array}{r}9.9 \\
49.4\end{array}$ & $\begin{array}{l}-41.3 \\
-520\end{array}$ & & & \\
\hline $\begin{array}{l}68 \mathrm{~A} \mathrm{~A} \cdot 3 \mathrm{3H}-3 \\
68 \mathrm{~B}-3 \mathrm{H} \cdot 4\end{array}$ & 23.98 & 19 & & $\begin{array}{l}7.3 \\
3.2\end{array}$ & & 2.5 & 0.7 & 2.0 & 2.8 & & & & $\begin{array}{l}265 \\
25\end{array}$ & $\begin{array}{l}97.7 \\
87.9\end{array}$ & & $\begin{array}{l}1.5 \\
7.9\end{array}$ & & $\begin{array}{l}0.5 \\
4.2\end{array}$ & 0.1 & 0.2 & & & $\begin{array}{l}0.02 \\
0.09\end{array}$ & $\begin{array}{r}4.4 .4 \\
7.3\end{array}$ & $\begin{array}{l}-52.0 \\
-51.7\end{array}$ & & & \\
\hline $686 \mathrm{~B}-6 \mathrm{X}$ & 49. & 582 & & 2.4 & & 1.3 & & & & & & & 586 & 99. & & 0.2 & & 0.1 & & & & & 0.00 & 332.3 & -69.8 & & & -191.0 \\
\hline $686 \mathrm{~B}-6 \mathrm{X}-3$ & 50. & 418 & & 4.3 & & 2.8 & & 0.9 & & & & & 426 & 99. & & 0.5 & & 0.2 & & 0.1 & & & & 127.1 & & & & -189.0 \\
\hline & & 575 & & 3.7 & & 3.0 & & & & & & & & 99. & & 0.3 & & 2 & & & & & & 187.7 & & & & -194.0 \\
\hline & 106.48 & 1111 & & 5.0 & & 2.5 & 0.4 & 4.0 & 4.4 & & & & 1127 & 99 & & 0.2 & & 0.1 & 0.0 & 0.1 & & & & 311.2 & -6 & & & -185.0 \\
\hline & $\begin{array}{l}139.45 \\
1.66 .45\end{array}$ & 919 & 0.3 & 4.7 & & 2.8 & 1.0 & 1.0 & 2.0 & 2.5 & 2.9 & 5.4 & $\begin{array}{r}942 \\
1193\end{array}$ & 99.5 & 0.0 & 0.3 & 00 & 0.1 & 0.0 & 0.0 & 0.1 & 0.1 & & $\begin{array}{l}261.7 \\
168.2\end{array}$ & & & & $\begin{array}{l}-183.0 \\
-155.0\end{array}$ \\
\hline $\begin{array}{l}686 \mathrm{~B}-1 \\
686 \mathrm{~B}-2\end{array}$ & $\begin{array}{l}166.45 \\
193.45\end{array}$ & $\begin{array}{l}1267 \\
1155\end{array}$ & $\begin{array}{l}0.7 \\
1.0\end{array}$ & $\begin{array}{l}10.3 \\
10.5\end{array}$ & 1.3 & $\begin{array}{l}5.6 \\
7.1\end{array}$ & $\begin{array}{l}1.4 \\
2.1\end{array}$ & $\begin{array}{l}1.9 \\
2.1\end{array}$ & $\begin{array}{l}3.2 \\
4.2\end{array}$ & & $\begin{array}{l}1.1 \\
1.6\end{array}$ & 7.9 & $\begin{array}{l}1293 \\
1198\end{array}$ & 99 & $\begin{array}{l}0.0 \\
0.1\end{array}$ & $\begin{array}{l}0.4 \\
0.5\end{array}$ & 0.0 & 0.2 & $\begin{array}{l}0.0 \\
0.1\end{array}$ & 0.0 & 0.1 & $\begin{array}{l}0.0 \\
0.0\end{array}$ & & $\begin{array}{l}168.2 \\
141.5\end{array}$ & $\begin{array}{l}-5 \\
-6\end{array}$ & & & $\begin{array}{l}-155.0 \\
-184.0\end{array}$ \\
\hline $\begin{array}{l}688 \mathrm{~B}-21 \mathrm{X}-2 \\
686 \mathrm{~B}-24 \mathrm{X}-2\end{array}$ & $\begin{array}{l}\begin{array}{l}193.45 \\
220.45\end{array} \\
\end{array}$ & $\begin{array}{l}1155 \\
2448\end{array}$ & $\begin{array}{l}1.0 \\
2.6\end{array}$ & $\begin{array}{l}10.5 \\
12.9\end{array}$ & 2.6 & $\begin{array}{l}7.1 \\
8.8\end{array}$ & $\begin{array}{l}2.1 \\
1.8\end{array}$ & $\begin{array}{l}2.1 \\
1.8\end{array}$ & $\begin{array}{l}4.2 \\
3.6\end{array}$ & ${ }_{2.2}^{6.3}$ & 1.6 & 7.9 & $\begin{array}{l}1198 \\
2484\end{array}$ & . 99. & $\begin{array}{l}0.1 \\
0.1\end{array}$ & $\begin{array}{l}0.5 \\
0.3\end{array}$ & 0.0 & $\begin{array}{l}0.2 \\
0.1\end{array}$ & $\begin{array}{l}0.1 \\
0.0\end{array}$ & $\begin{array}{l}0.1 \\
0.0\end{array}$ & $\begin{array}{l}0.1 \\
0.0\end{array}$ & 0.0 & $\begin{array}{l}0.01 \\
0.00\end{array}$ & $\begin{array}{l}142.5 \\
242.5\end{array}$ & $\begin{array}{l}-64.9 \\
-64.4\end{array}$ & & & $\begin{array}{l}-184.0 \\
-175.0\end{array}$ \\
\hline & 262.95 & 1323 & 0.7 & 28.5 & & 27.4 & 17.3 & 6.9 & 24.3 & 51.7 & 1.8 & 53.5 & 1535 & 96 & 0.0 & 1.1 & & 0.7 & 0.4 & 0.1 & 0.8 & 0.0 & & 52.6 & -64.0 & & & -182.0 \\
\hline & 296.45 & 933 & & 7.0 & & 3.4 & 1.7 & 2.0 & 3.7 & 3.8 & & & 955 & & & 0.4 & & 0. & 0.1 & 0.1 & 0.1 & & & 187.3 & -64.1 & & & -195.0 \\
\hline & & 9 & 0.0 & 1.4 & 0.0 & 1.5 & 0.0 & 0.5 & 0.5 & 0.0 & 0.0 & 0.0 & 13 & 86 & 0.0 & 7.0 & 0.0 & 5.2 & 0.0 & 1.3 & 0.0 & 0.0 & & 7.1 & -33.2 & & & \\
\hline $687 \mathrm{~B}-6$ & 50.68 & 624 & 0.0 & 20.0 & 0.0 & 10.2 & 2.8 & 8.8 & 11.6 & 3.2 & 0.6 & 3.8 & 685 & 97,1 & 0.0 & 1.7 & 0.0 & 0.6 & 0.1 & 0.4 & 0.1 & 0.0 & 0. & $\begin{array}{l}43.4 \\
5.4\end{array}$ & -38.3 & & & \\
\hline $\begin{array}{l}687 \mathrm{~B}-7 \mathrm{H}-1 \\
687-9 \mathrm{H}-3\end{array}$ & $\begin{array}{l}54.18 \\
75.78\end{array}$ & $\begin{array}{l}{ }_{801}^{237} \\
801\end{array}$ & $\begin{array}{l}1.0 \\
0.0\end{array}$ & $\begin{array}{r}5.7 \\
10.5\end{array}$ & $\begin{array}{l}2.1 \\
0.0\end{array}$ & $\begin{array}{l}4.4 \\
3.6\end{array}$ & 0.9 & $\begin{array}{l}2.6 \\
3.2\end{array}$ & $\begin{array}{l}3.5 \\
3.8\end{array}$ & $\begin{array}{l}0.0 \\
2.5\end{array}$ & $\begin{array}{l}0.5 \\
0.0\end{array}$ & $\begin{array}{l}0.5 \\
2.5\end{array}$ & $\begin{array}{l}258 \\
828\end{array}$ & $\begin{array}{l}97.1 \\
99.0\end{array}$ & 0.2 & $\begin{array}{l}1.2 \\
0.7\end{array}$ & $\begin{array}{l}0.3 \\
0.0\end{array}$ & $\begin{array}{l}0.7 \\
0.2\end{array}$ & $\begin{array}{l}0.1 \\
0.0\end{array}$ & $\begin{array}{l}0.3 \\
0.1\end{array}$ & $\begin{array}{l}0.0 \\
0.1\end{array}$ & $\begin{array}{l}0.1 \\
0.0\end{array}$ & $\begin{array}{l}0.01 \\
0.01\end{array}$ & $\begin{array}{r}51.4 \\
116.4\end{array}$ & $\begin{array}{l}-75.6 \\
-66.9\end{array}$ & & & \\
\hline $\begin{array}{l}687 \mathrm{~B}-\mathrm{B}-15 \mathrm{~A}-3 \\
67 \mathrm{X}-1\end{array}$ & $\begin{array}{l}75.78 \\
120.78\end{array}$ & $\begin{array}{l}801 \\
580\end{array}$ & $\begin{array}{l}0.0 \\
0.3\end{array}$ & $\begin{array}{r}10.5 \\
7.2\end{array}$ & $\begin{array}{l}0.0 \\
0.0\end{array}$ & $\begin{array}{l}3.6 \\
2.9\end{array}$ & $\begin{array}{l}0.6 \\
1.7\end{array}$ & $\begin{array}{l}3.2 \\
1.7\end{array}$ & $\begin{array}{l}3.8 \\
3.4\end{array}$ & $\begin{array}{l}2.5 \\
5.0\end{array}$ & $\begin{array}{l}0.0 \\
0.0\end{array}$ & $\begin{array}{l}2.5 \\
5.0\end{array}$ & $\begin{array}{l}828 \\
98.8\end{array}$ & $\begin{array}{r}99.0 \\
0.0\end{array}$ & $\begin{array}{l}0.0 \\
0.7\end{array}$ & $\begin{array}{l}0.7 \\
0.0\end{array}$ & $\begin{array}{l}0.0 \\
0.2\end{array}$ & $\begin{array}{l}0.2 \\
0.1\end{array}$ & $\begin{array}{l}0.0 \\
0.1\end{array}$ & $\begin{array}{l}0.1 \\
0.2\end{array}$ & $\begin{array}{l}0.1 \\
0.0\end{array}$ & $\begin{array}{l}0.0 \\
0.01\end{array}$ & $\begin{array}{r}0.01 \\
119.0\end{array}$ & $\begin{array}{l}116.4 \\
-65.4\end{array}$ & -00.9 & & & \\
\hline
\end{tabular}


Table 2. Molecular and isotope composition of free- and "true sorbed"-gas fractions.

\begin{tabular}{|c|c|c|c|c|c|c|c|c|c|c|c|c|c|c|c|c|c|c|c|c|c|c|c|c|c|}
\hline \multirow[b]{2}{*}{ Core, section } & \multirow[b]{2}{*}{$\begin{array}{l}\text { Depth } \\
\text { (mbsf) }\end{array}$} & \multicolumn{10}{|c|}{ Hydrocarbon yield (ppb dry sediment wt. basis) } & \multicolumn{9}{|c|}{ Hydrocarbon \% (vol. basis) } & \multirow[b]{2}{*}{$\begin{array}{l}\mathbf{C}_{2}^{\prime} \\
\mathbf{C}_{1}\end{array}$} & \multirow{2}{*}{$\begin{array}{l}\mathrm{C}_{1} \\
\mathrm{C}_{2}+\mathrm{c}_{3}\end{array}$} & \multirow[b]{2}{*}{$\begin{array}{l}{ }^{813} \mathrm{C}_{1} \\
\left(\xi_{c}\right)\end{array}$} & \multirow[b]{2}{*}{${ }_{(\% e)}^{{ }^{13} \mathrm{C}_{2}}$} & \multirow[b]{2}{*}{$\underset{\left(\%()_{1}\right)}{\delta \mathrm{D}-\mathrm{C}_{1}}$} \\
\hline & & $\mathrm{CH}_{4}$ & $\mathrm{C}_{2} \mathrm{H}_{4}$ & $\mathrm{C}_{2} \mathrm{H}_{6}$ & $\mathrm{C}_{3} \mathrm{H}_{6}$ & $\mathrm{C}_{3} \mathrm{H}_{8}$ & $i-\mathrm{C}_{4}$ & $\begin{array}{l}n- \\
\mathrm{c}_{4}\end{array}$ & $i-\mathrm{C}_{5}$ & $\stackrel{n-}{c_{5}}$ & $\begin{array}{l}\text { Total } \\
C_{1} / \\
C_{5}\end{array}$ & $\mathrm{CH}_{4}$ & $\mathrm{C}_{2} \mathrm{H}_{4}$ & $\mathrm{C}_{2} \mathrm{H}_{6}$ & $\mathrm{C}_{3} \mathrm{H}_{6}$ & $\mathrm{C}_{3} \mathrm{H}_{8}$ & $\stackrel{i .}{\mathrm{C}_{4}}$ & $\begin{array}{l}n \cdot \\
C_{4}\end{array}$ & $\stackrel{i \cdot}{\mathrm{C}_{5}}$ & $\mathrm{c}_{5}^{n-}$ & & & & & \\
\hline \multicolumn{26}{|l|}{ True sorbed gas } \\
\hline $112.679 \mathrm{D}-5 \mathrm{H}(>63 \mu \mathrm{m})$ & 42.8 & 747.0 & 12.0 & 0.0 & 211 & 91.0 & 15.0 & 36.0 & 21.0 & 14.0 & 1147 & 81.1 & 0.8 & 0.0 & 12.2 & 3.6 & 0.5 & 1.1 & 0.5 & 0.3 & 0.15 & 5 & -37.9 & -26.4 & -190.0 \\
\hline 679D-5H $(<63 \mu \mathrm{m})$ & 42.8 & 1700.0 & 0.0 & 0.0 & 185 & 97.0 & 22.0 & 39.0 & 22.0 & 4.0 & 2069 & 91.52 & 0.0 & 0.0 & 5.3 & 1.9 & 0.3 & 0.6 & 0.3 & 0.1 & 0.06 & 12 & -38.9 & -29.7 & \\
\hline $679 \mathrm{D}-14 \mathrm{H}$ & 116.7 & 20.0 & 1.0 & 0.0 & 4.0 & 1.0 & 1.0 & 0.0 & 0.0 & 0.0 & 27 & 83 & 3.7 & 0.0 & 9.2 & 2.3 & 1.2 & 0.7 & 0.0 & 0.0 & 0.11 & 7 & -39.8 & & \\
\hline $679 \mathrm{D}-18 \mathrm{X}, \mathrm{CC}$ & 156.0 & 51.0 & 0.0 & 0.0 & 6.0 & 3.0 & 0.0 & 1.0 & 0.0 & 0.0 & 61 & 90.68 & 0.0 & 0.0 & 6.0 & 2.2 & 0.1 & 0.9 & 0.0 & 0.0 & 0.07 & 10 & -47.4 & & \\
\hline $682 \mathrm{~A}-18 \mathrm{X}, \mathrm{CC}$ & 164.3 & 1000.0 & 1.0 & 0.0 & 14.0 & 7.0 & 4.0 & 4.0 & 10.0 & 1.0 & 1041 & 98.42 & 0.1 & 0.0 & 0.8 & 0.3 & 0.1 & 0.1 & 0.2 & 0.0 & 0.01 & 94 & -67.7 & -190.0 & \\
\hline $682 \mathrm{~A}-39 \mathrm{X}, \mathrm{CC}(1-4 \mathrm{~cm})$ & 352.2 & 626.0 & 16.0 & 1.0 & 19.0 & 11.0 & 2.0 & 5.0 & 4.0 & 3.0 & 687 & 96.92 & 1.5 & 0.1 & 1.6 & 0.7 & 0.1 & 0.3 & 0.1 & 0.1 & 0.02 & 43 & -58.0 & 150.0 & \\
\hline \multicolumn{26}{|l|}{ Free gas } \\
\hline $112-679 \mathrm{D}-5 \mathrm{H}, \mathrm{CC}$ & 42.8 & 2 & 0 & 0 & 0 & 0 & 0 & 0 & 0 & 0 & 2 & 100 & 0.0 & 0.0 & 0.0 & 0.0 & 0.0 & 0.0 & 0.0 & 0.0 & & & & & \\
\hline $679 \mathrm{D}-14 \mathrm{H}$ & 116.7 & 3 & 0 & 0 & 0 & 0 & 0 & 0 & 0 & 0 & 3 & 100 & 0.0 & 0.0 & 0.0 & 0.0 & 0.0 & 0.0 & 0.0 & 0.0 & & & & & \\
\hline $679 \mathrm{D}-18 \mathrm{X}, \mathrm{CC}$ & 156.0 & 2 & 0 & 0 & 0 & 0 & 0 & 0 & 0 & 0 & 2 & 100 & 0.0 & 0.0 & 0.0 & 0.0 & 0.0 & 0.0 & 0.0 & 0.0 & & & & & \\
\hline $682 \mathrm{~A} \cdot 18 \mathrm{X}, \mathrm{CC}$ & 164.3 & 2 & 0 & 0 & 0 & 0 & 0 & 0 & 0 & 0 & 2 & 100 & 0.0 & 0.0 & 0.0 & 0.0 & 0.0 & 0.0 & 0.0 & 0.0 & & & & & \\
\hline $682 \mathrm{~A}, 39 \mathrm{X}, \mathrm{CC}(1-4 \mathrm{~cm})$ & 352.2 & 3 & 0 & 0 & 0 & 0 & 0 & 0 & 0 & 0 & 3 & 100 & 0.0 & 0.0 & 0.0 & 0.0 & 0.0 & 0.0 & 0.0 & 0.0 & & & & & \\
\hline
\end{tabular}
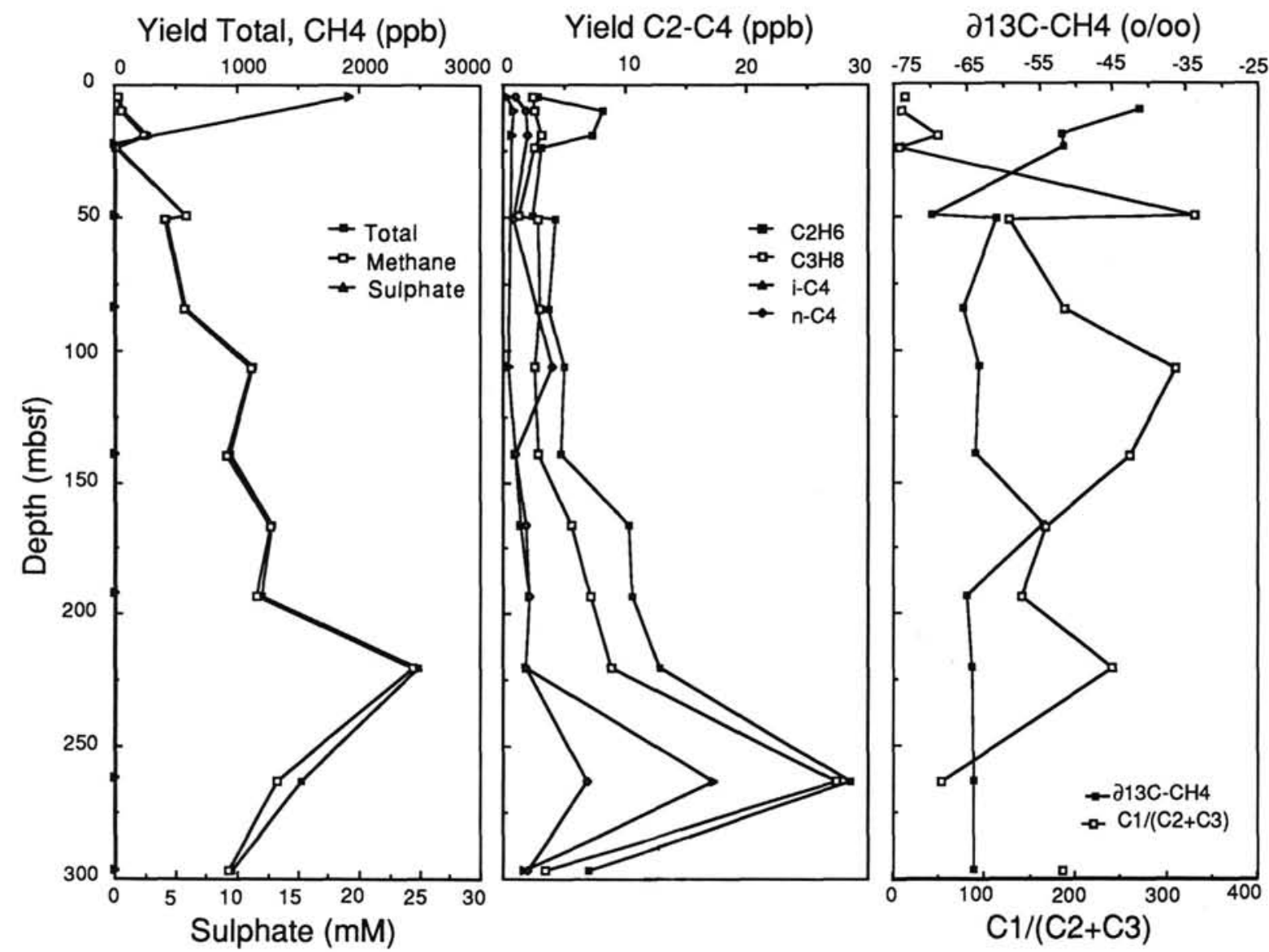

Figure 9. Molecular and isotope data of sorbed gases and dissolved sulfate from Site 686.

the vitrinite reflectance of source rock and the corresponding carbon-isotope ratios of methane, ethane, and propane (Faber, 1987: Faber and Whiticar, 1989). These generalized relationships are as follows:

$$
\begin{aligned}
& \log (\% \text { Ro-equiv. })=0.065\left(\delta^{13} \mathrm{C}_{\mathrm{CH}_{4}}\right)+2.68 . \\
& \log (\% \text { Ro-equiv. })=0.044\left(\delta^{13} \mathrm{C}_{\mathrm{C}_{2} \mathrm{H}_{6}}\right)+1.42 . \\
& \log (\% \text { Ro-equiv. })=0.048\left(\delta^{13} \mathrm{C}_{\mathrm{C}_{3} \mathrm{H}_{8}}\right)+1.42 .
\end{aligned}
$$

The $\delta^{13} \mathrm{C}_{\mathrm{C}_{2} \mathrm{H}_{6}}$ and $\delta^{13} \mathrm{C}_{\mathrm{C}_{3} \mathrm{H}_{8}}$ ratios measured at Sites 679 and 680 cluster around the values of -28 and $-26 \%$, respectively
(Fig. 11). Both these isotope ratios correspond to a kerogen maturity of about $1.5 \%$ Ro-equiv. Similarly, the methaneethane pairs $\left(\delta^{13} \mathrm{C}_{\mathrm{CH}_{4}}\right.$ ca. $-38 \%, \delta^{13} \mathrm{C}_{\mathrm{C}_{2} \mathrm{H}_{6}}$ about $-28 \%$ ) lying on the line of Equation 2 indicate kerogen maturity of about $1.6 \%$ Ro-equiv. Those above the line suggest an even more mature source for the methane, or again, a Type III kerogen influence.

In comparison with the isotope ratios at Sites 679 and 680 , the $\delta^{13} \mathrm{C}_{\mathrm{C}_{2} \mathrm{H}_{6}}$ and $\delta^{13} \mathrm{C}_{\mathrm{C}_{3} \mathrm{H}_{8}}$ ratios measured at Site 682 are both more depleted in ${ }^{13} \mathrm{C}$ and indicate a more immature source (\%Ro-equiv. about 0.7 to 0.8 ). The influence of bacterial methane on these samples precludes a maturity estimate based on $\delta^{13} \mathrm{C}_{\mathrm{CH}_{4}}$. Sample 112-679D-10H, CC (86.62 mbsf), shown in Figure 11, is a misfit for both $\delta^{13} \mathrm{C}_{\mathrm{CH}_{4}}$ and $\delta^{13} \mathrm{C}_{\mathrm{C}_{3} \mathrm{H}_{6}}$, 

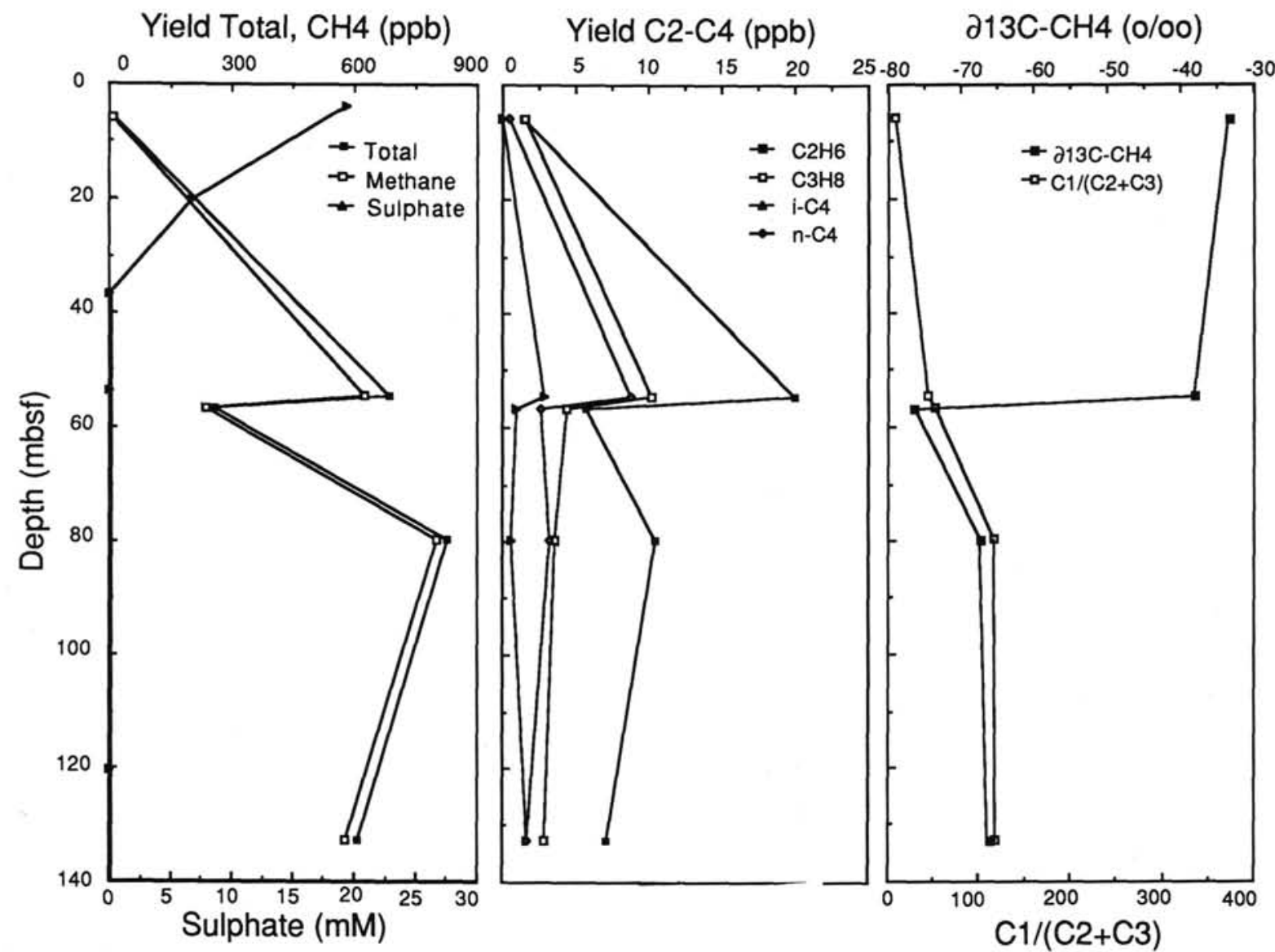

Figure 10. Molecular and isotope data of sorbed gases and dissolved sulfate from Site 687.

but as mentioned before, this sample is analytically suspect.

The maturity estimates for Sites 679 and 680 suggest that the source of organic matter is over-mature; however, this organic matter, where the thermogenic hydrocarbons were found, is immature. This discrepancy between the estimated maturities of the hydrocarbon gases and the cored material supports the idea that these hydrocarbon gases migrated from a source location of significantly higher maturity. In contrast, the low maturity and bacterial character of the hydrocarbon gases at the reference Site 682 indicate that they are produced at or near the depth where they were encountered.

\section{COMPARISON OF TOTAL, FREE, SORBED AND HEADSPACE GAS SAMPLE TYPES}

In the Leg 112 analytical program, a variety of analytical methods were employed to determine the compositions of the hydrocarbon gas types. These types of sample analysis are vacutainer, headspace-gas and canned-gas procedures (see Kvenvolden et al., this volume), and the sorbed-gas procedure reported here. In addition to these sorbed-gas determinations, the free and "true sorbed" gas fractions were analyzed from three depth intervals from Site 679 and from two depth intervals from Site 682 (Table 2).

The free-gas concentrations in all the samples from both sites are very low ( 2 to $3 \mathrm{ppb}$ ), and this free gas primarily consists of methane. Isotope measurements could not be performed with quantities of gas this small. Similarly, at Site 679 the headspace- and canned-gas procedures show low gas yields (Kvenvolden et al., this volume). In contrast, at Site 682 with the headspace- and canned-gas procedures we de- tected relatively high yields of methane, which were not found in the free-gas fraction. In our samples it appears likely that most of the loosely bound, free gas had escaped from the sediments prior to being analyzed (i.e., during sampling and/or pumping). This interpretation of the loss of free gases is supported by the comparison of sorbed-gas with total-gas fractions, discussed next.

The results of the five "true sorbed" gas sample intervals analyzed (Table 2) are essentially indistinguishable from those of the corresponding sorbed-gas fraction (Table 1). In addition, the sorbed gases of the sediment size fractions $>63 \mu \mathrm{m}$ and $>63 \mu \mathrm{m}$, from one of the samples (112-679D-5H, CC) also showed little variation. The hydrocarbon yields of the sorbedgas fraction closely track that of the "true sorbed" gas fraction (compare Fig. 2, Table 1, with Table 2), despite the range in hydrocarbon yields present (yield $\mathrm{C}_{1-4}=76$ to 1830 $\mathrm{ppb}$ ). The molecular and methane carbon isotope compositions are also similar for the two sorbed-gas types (compare Fig. 2, Table 1 with Table 2). This demonstrates that the minor quantities of free gases do not significantly influence the sorbed gases measured. In addition, these extra gas measurements of the "true sorbed" gas fraction also indirectly demonstrate the acceptable analytical reproducibility of the sorbed-gas procedure. The "true sorbed" gas data strengthen the fact that the anomaly of higher hydrocarbons in the upper 100 mbsf at Site 679 is real and contrasts markedly with the character of the hydrocarbon gas in the underlying sediments. Based on single sample results, the sediment size fraction does not significantly influence the outcome.

The greater methane or $C_{2+}$ concentrations in the "true sorbed"' and sorbed-gas fractions of the Pliocene sediments at 


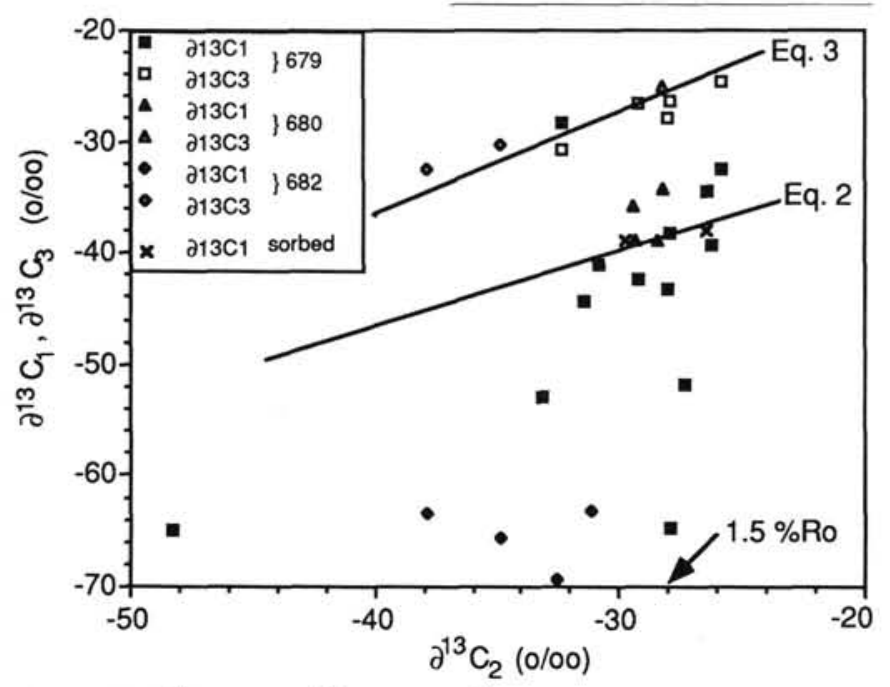

Figure 11. $\delta^{13} \mathrm{C}_{\mathrm{CH}_{4}}$ and $\delta^{13} \mathrm{C}_{\mathrm{C}_{3} \mathrm{H}_{8}}$ vs. $\delta^{13} \mathrm{C}_{\mathrm{C}_{2} \mathrm{H}_{6}}$ of sorbed gases, showing mixture of a bacterial methane with a thermogenic gas type. Maturity estimate of the source matter is $1.5 \%$ Ro-equivalent (indicated on the $\delta^{13} \mathrm{C}_{\mathrm{C}_{2} \mathrm{H}_{6}}$ axis) based on mean $\mathrm{C}_{1}, \mathrm{C}_{2}$, and $\mathrm{C}_{3}$ isotope values. Equations 2 (methane-ethane) and 3 (propane-ethane) are defined in text.

Site 679 (i.e., at 42.85 mbsf: total $C_{2-5}=529 \mathrm{ppb}$; sorbed $\mathrm{C}_{2-5}$ $=388 \mathrm{ppb}$ ) are not measured in the free-, canned- or headspace-gas data (i.e., at 51.5 mbsf canned gas $\mathrm{C}_{2}=7$ to $9 \mathrm{ppb}$ wt dry sediment; Table 2 , see Kvenvolden et al., this volume). Thus, the signal of elevated hydrocarbon contents in the Pliocene sediments at Site 679, associated with the intrusion of hypersaline fluid, can be detected only within the sorbedgas fraction. The molecular and isotope compositions of the sorbed-gas fraction indicate that this gas may have a thermogenic source and that it has migrated westward into the Lima Basin.

\section{CONCLUSIONS}

Bacterial and thermogenic hydrocarbon gases are present in the sorbed-gas fraction of Peru margin sediments. These bacterial gases, at Sites 682,684 and 686 , are restricted to the early diagenetic zones, where dissolved sulfate has been exhausted, and methane has been profusely generated. The primary methanogenic pathway was carbonate reduction, with an isotope discrimination factor $\left(\alpha_{\mathrm{CO}_{2}-\mathrm{CH}_{4}}\right)$ of 1.07 to 1.08. Methane that diffused upward into the sulfate-reducing zone at Site 686 has been anaerobically oxidized. In these sediments, the microbial consumption maintained the low methane concentrations and caused the isotope shift in $\delta^{13} \mathrm{C}_{\mathrm{CH}_{4}}$ to more positive values. The same process may have been active in the upper section of Site 684. Significant amounts of $\mathrm{C}_{2+}$ hydrocarbons occur at Sites 680/681, 684, 686/687, where these hydrocarbons appear to have been associated with hypersaline fluids. There is evidence that hypersaline fluids have intruded into the sediments of the upper sections at Site 679 and that the migration of $\mathrm{C}_{2+}$ hydrocarbons there is somehow related to these fluids.

The greater $\mathrm{C}_{2+}$ concentrations in the sorbed-gas fractions of the sediments at Site 679, are not measured in the "free-," "canned-," or "headspace-gas" data. Thus, the signal of hydrocarbons in the sediments associated with the intrusion of hypersaline fluid, can be detected only within the sorbed-gas fraction, which has been protected from bacterial influence. The molecular and isotope compositions of the sorbed-gas fraction indicate that this gas may have had a thermogenic source and may have migrated westward down the flank into the Lima Basin. The thermogenic hydrocarbon gases are over-mature (about $1.5 \%$ Ro-equiv.) and are discordant with the low mature sediments wherein they were found. This further supports the process of migration of these hydrocarbons, possibly from continental (onshore) sources. Sorbedgas analyses provide important geochemical information in addition to that obtained from free-gas data. Essentially, the $\mathrm{C}_{2+}$ sorbed-gases are less sensitive to activities in the interstitial fluids, such as methanogenesis and methanotrophy, and may have faithfully recorded the migration of thermogenic hydrocarbons associated with the hypersaline fluids in the Lima Basin.

\section{ACKNOWLEDGMENTS}

We would like to thank J. Brooks, K. Kvenvolden, and M. Tarafa for reviewing the manuscript, and K.-C. Emeis for editorial work. This work was financed by BMFT Grant O3E 6237 (MJW) and USSAC (ES).

\section{REFERENCES}

Faber, E., 1987. Zur Isotopengeochemie gasförmiger Kohlenwasserstofte. Erdöl Erdgas Kohle, 103:210-218.

Faber, E., and Stahl, W., 1983. Analytic procedure and results of an isotope geochemical surface survey in an area of the British North Sea. In Brooks, J. (Ed.), Petroleum Geochemistry and Exploration of Europe: London (Blackwell), 51-623.

Faber, E., and Whiticar, M. J., in press. Isotope geochemistry of natural gases. Org. Geochem.

Shipboard Scientific Party, 1988a. Site 679. In Suess, E., von Huene, R., et al., Proc. ODP, Init. Repts., 112: College Station, TX (Ocean Drilling Program), 159-248.

1988b. Site 680. In Suess, E., von Huene, R., et al., Proc. ODP, Init. Repts., 112: College Station, TX (Ocean Drilling Program), 249-303.

1988c. Site 684. In Suess, E., von Huene, R., et al., Proc. ODP, Init. Repts., 112: College Station, TX (Ocean Drilling Program), 525-595.

Suess, E., and Whiticar, M. J., 1989. Methane-derived $\mathrm{CO}_{2}$ in pore fluids expelled from the Oregon subduction complex. Palaeogeogr., Palaeoclimatol., Palaeoecol., 71:119-136.

Suess, E., and Müller, P. J., 1980. Productivity sedimentation rate and sedimentary organic matter in the oceans, II. Elemental fractionation. Coll. Int. CNRS, 293:17-26.

Suess, E., von Huene, R., et al., 1988. ODP Leg 112, Peru continental margin: Part 2, sedimentary history and diagenesis in a coastal upwelling environment. Geology, 16:939-943.

von Huene, R., Suess, E., et al., 1988. ODP Leg 112, Peru continental margin: Part 1, tectonic history. Geology, 16:934-938.

Whiticar, M. J., and Faber, E., 1986. Methane oxidation in sediment and water column environments-isotope evidence. In Leythaueser, D., and Rullkötter, J. (Eds.), Advances in Organic Geochemistry, 1985. Org. Geochem., 10:759-768.

1989. Molecular and stable isotope composition of headspace and total hydrocarbon gases at ODP Leg 104, Sites 642, 643, and 644, Vøring Plateau, Norwegian Sea. In Eldholm, O., and Thiede, J., et al., Proc. ODP, Sci. Results, 104: College Station, TX (Ocean Drilling Program), 327-334.

Whiticar, M. J., Faber, E., and Schoell, M., 1986. Biogenic methane formation in marine and freshwater environments: $\mathrm{C} 02$ reduction vs. acetate fermentation-isotope evidence. Geochim. Cosmochim. Acta., 50:693-709.

Date of initial receipt: 25 August 1988

Date of acceptance: 25 August 1989

Ms 112B-165 